\title{
Peer review of the pesticide risk assessment of the active substance benthiavalicarb (variant assessed benthiavalicarb-isopropyl)
}

\author{
European Food Safety Authority (EFSA), \\ Fernando Alvarez, Maria Arena, Domenica Auteri, Jorge Borroto, Alba Brancato, \\ Luis Carrasco Cabrera, Anna Federica Castoldi, Arianna Chiusolo, Angelo Colagiorgi, \\ Mathilde Colas, Federica Crivellente, Chloe De Lentdecker, Mark Egsmose, Gabriella Fait, \\ Franco Ferilli, Varvara Gouliarmou, Luna Greco, Alessio Ippolito, Frederique Istace, \\ Samira Jarrah, Dimitra Kardassi, Aude Kienzler, Renata Leuschner, Roberto Lava, \\ Alberto Linguadoca, Christopher Lythgo, Oriol Magrans, Iris Mangas, Ileana Miron, \\ Tunde Molnar, Laura Padovani, Juan Manuel Parra Morte, Ragnor Pedersen, Hermine Reich, \\ Miguel Santos, Rachel Sharp, Csaba Szentes, Andrea Terron, Manuela Tiramani, \\ Benedicte Vagenende and Laura Villamar-Bouza
}

\begin{abstract}
The conclusions of the EFSA following the peer review of the initial risk assessments carried out by the competent authorities of the rapporteur Member State, Poland, and co-rapporteur Member State, France, for the pesticide active substance benthiavalicarb (variant assessed benthiavalicarb-isopropyl) are reported. The context of the peer review was that required by Commission Implementing Regulation (EU) No 844/2012, as amended by Commission Implementing Regulation (EU) No 2018/ 1659. The conclusions were reached on the basis of the evaluation of the representative use of benthiavalicarb-isopropyl as a fungicide on potato (field use). The peer review also provided considerations on whether exposure to humans and the environment from the representative uses of benthiavalicarb-isopropyl can be considered negligible, taking into account the European Commission's draft guidance on this topic. The reliable end points, appropriate for use in regulatory risk assessment, are presented. Missing information identified as being required by the regulatory framework is listed. Concerns are identified. An evaluation of data concerning the necessity of benthiavalicarb-isopropyl as a fungicide to control a serious danger to plant health which cannot be contained by other available means, including non-chemical methods, is also presented.
\end{abstract}

(c) 2021 European Food Safety Authority. EFSA Journal published by John Wiley and Sons Ltd on behalf of European Food Safety Authority.

Keywords: benthiavalicarb, benthiavalicarb-isopropyl, peer review, risk assessment, pesticide, fungicide

Requestor: European Commission

Question number: EFSA-Q-2016-00666

Correspondence: pesticides.peerrevieew@efsa.europa.eu 
Note: This scientific output, approved on 23 August 2021, supersedes the previous output published on 1 August 2007 (EFSA, 2007).

Declarations of interest: The declarations of interest of all scientific experts active in EFSA's work are available at https://ess.efsa.europa.eu/doi/doiweb/doisearch.

Acknowledgements: EFSA wishes to thank the rapporteur Member State, Poland, for the preparatory work on this scientific output.

Suggested citation: EFSA (European Food Safety Authority), Alvarez F, Arena M, Auteri D, Borroto J, Brancato A, Carrasco Cabrera L, Castoldi AF, Chiusolo A, Colagiorgi A, Colas $M$, Crivellente $F$, De Lentdecker C, Egsmose M, Fait G, Ferilli F, Gouliarmou V, Greco L, Ippolito A, Istace F, Jarrah S, Kardassi D, Kienzler A, Leuschner R, Lava R, Linguadoca A, Lythgo C, Magrans O, Mangas I, Miron I, Molnar T, Padovani L, Parra Morte JM, Pedersen R, Reich H, Santos M, Sharp R, Szentes C, Terron A, Tiramani M, Vagenende B and Villamar-Bouza L, 2021. Conclusion on the peer review of the pesticide risk assessment of the active substance benthiavalicarb (variant assessed benthiavalicarb-isopropyl). EFSA Journal 2021;19(9):6833, 31 pp. https://doi.org/10.2903/j.efsa.2021.6833

ISSN: $1831-4732$

(C) 2021 European Food Safety Authority. EFSA Journal published by John Wiley and Sons Ltd on behalf of European Food Safety Authority.

This is an open access article under the terms of the Creative Commons Attribution-NoDerivs License, which permits use and distribution in any medium, provided the original work is properly cited and no modifications or adaptations are made.

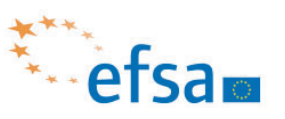

The EFSA Journal is a publication of the European Food Safety Authority, a European agency funded by the European Union. 


\section{Summary}

Commission Implementing Regulation (EU) No 844/2012, as amended by Commission Implementing Regulation (EU) No 2018/1659, lays down the procedure for the renewal of the approval of active substances submitted under Article 14 of Regulation (EC) No 1107/2009. The list of those substances is established in Commission Implementing Regulation (EU) No 686/2012. Benthiavalicarb is one of the active substances listed in Regulation (EU) No 686/2012.

In accordance with Article 1 of Regulation (EU) No 844/2012, the rapporteur Member State (RMS), Poland, and co-rapporteur Member State (co-RMS), France, received an application from K-I Chemical Europe SA/NV for the renewal of approval of the active substance benthiavalicarb.

An initial evaluation of the dossier on benthiavalicarb which assessed the derivative benthiavalicarbisopropyl was provided by the RMS in the renewal assessment report (RAR) and subsequently, a peer review of the pesticide risk assessment on the RMS evaluation was conducted by EFSA in accordance with Article 13 of Commission Implementing Regulation (EU) No 844/2012, as amended by Commission Implementing Regulation (EU) No 2018/1659.

Benthiavalicarb-isopropyl has been concluded to meet the cut-off criteria for non-approval, Annex II, point 3.6.5 of Regulation (EC) No 1107/2009 as amended by Commission Regulation (EU) No 2018/605 concerning endocrine disrupting potential. As part of the renewal procedure, the applicant provided further information that aimed to demonstrate that the exposure of humans to benthiavalicarb-isopropyl was negligible under realistic conditions of use. Benthiavalicarb-isopropyl has therefore been assessed under the provisions of negligible exposure to satisfy point 3.6.5 of Annex II of Regulation 1107/2009 as amended by Commission Regulation (EU) No 2018/605. Furthermore, the applicant requested a derogation under Article 4(7) of Regulation (EC) 1107/2009, submitting evidence regarding the necessity of benthiavalicarb-isopropyl to control a serious danger to plant health. The evaluation of the data regarding this derogation request is presented in Appendices $C$ and $D$ to this conclusion.

Following completion of the peer review, the following conclusions are derived.

The representative use of benthiavalicarb-isopropyl by spraying with tractor-mounted equipment as a fungicide on potato, as proposed at EU level results in a sufficient fungicidal efficacy against the target disease, late blight.

There were not any critical issues identified in the section identity, physical-chemical and technical properties of the active substance and the representative formulation and the analytical methods.

In the area of mammalian toxicology, the following issues not finalised were identified: compliance of the batches used in the toxicological studies with the technical specification; identification of unique human metabolites and the assessment of the adequateness of the animal species used for the toxicological assessment. A critical area of concern was identified with regard to the carcinogenic potential observed in liver and uterus in two different species. At the first tier of the negligible exposure assessment according to the available draft Technical Guidance Document on assessment of negligible exposure, the predicted non-dietary exposure was demonstrated to be below $10 \%$ of the (A)AOEL for all groups (operators, workers, bystanders and residents); while at the second tier, the margin of exposure with regard to the carcinogenic effect was higher than 1,000 for all groups.

The consumer dietary risk assessment in the residue section could not be finalised since the residue definitions for rotational crops remain open. In view this open issue a robust livestock exposure assessment via rotational crop feed items could not be conducted. As regards negligible exposure assessment according to the available draft Technical Guidance Document on assessment of negligible exposure, for the representative use, concentrations of residues of benthiavalicarb-isopropyl $<0.01 \mathrm{mg} / \mathrm{kg}$ were only demonstrated for potatoes. However, for the representative use, it could not be excluded that residues in other food items (rotational crops) could occur and be above the level of $0.01 \mathrm{mg} / \mathrm{kg}$.

The data available on environmental fate and behaviour are sufficient to carry out the required environmental exposure assessments at EU level for the representative uses; however, the consumer risk assessment could not be finalised as information was not available regarding the effect of water treatment processes on the nature of residues of the benthiavalicarb-isopropyl transformation products that might be present in surface water, when surface water is abstracted for the production of drinking water.

In the area of ecotoxicology, no critical areas of concern or issues that could not be finalised were identified. 
Benthiavalicarb-isopropyl is considered to meet the criteria for endocrine disruption for humans for the thyroid $(T)$ and oestrogen, androgen and steroidogenesis (EAS) modalities according to point 3.6.5 of Annex II of Regulation No 1107/2009, as amended by Commission Regulation (EU) 2018/605, leading to a critical area of concern. A conclusion on the endocrine-disrupting properties of benthiavalicarb-isopropyl for non-target organisms according to point 3.8.2 of Annex II to Regulation (EC) No 1107/2009, as amended by Commission Regulation (EU) 2018/605 could not be reached based on the information available. 


\section{Table of contents}

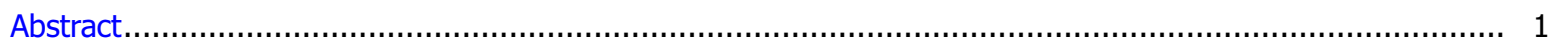

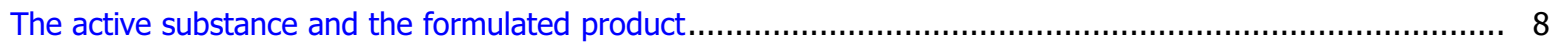

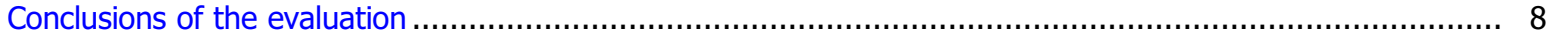

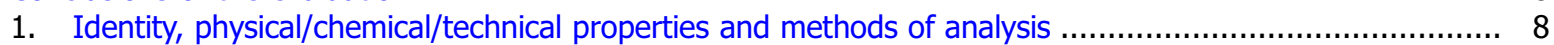

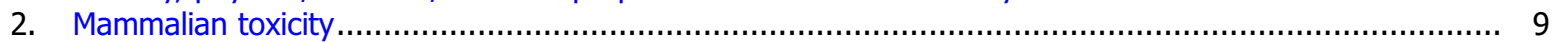

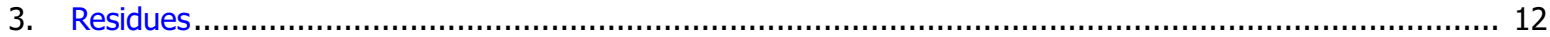

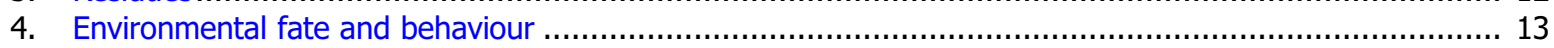

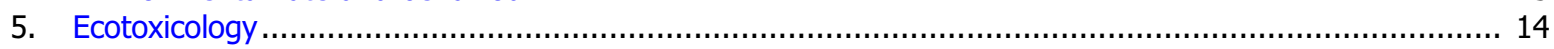

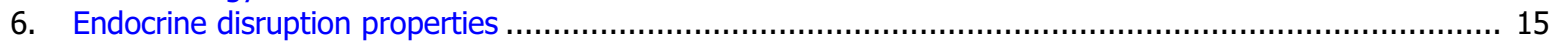

7. Overview of the risk assessment of compounds listed in residue definitions triggering assessment of

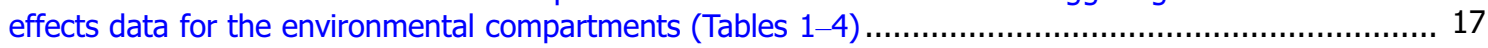

8. Particular conditions proposed to be taken into account by risk managers ................................... 18

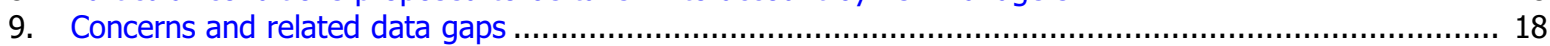

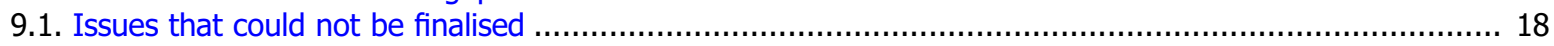

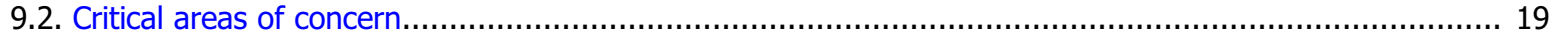

9.3. Overview of the concerns identified for each representative use considered (Table 5) ........................ 19

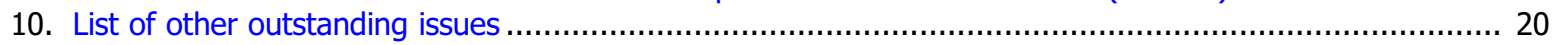

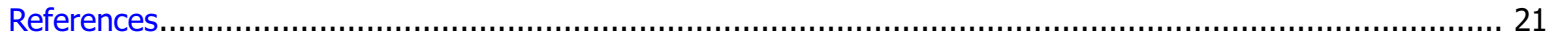

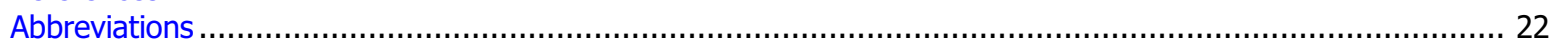

Appendix A - Consideration of cut-off criteria for benthiavalicarb according to Annex II of Regulation (EC) No

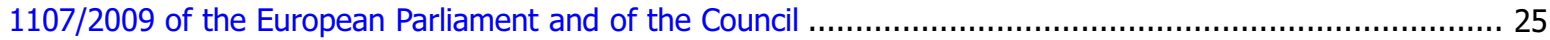

Appendix B - List of end points for the active substance and the representative formulation............................26

Appendix C - Evaluation of data concerning the necessity of benthiavalicarb as a fungicide to control a serious danger to plant health which cannot be contained by other available means, including non-chemical methods.....

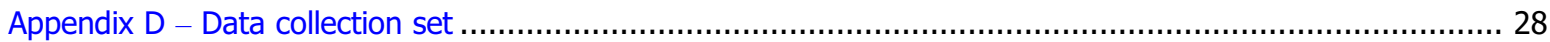
Appendix E - Wording EFSA used in section 4 of this conclusion, in relation to DT and Koc 'classes' exhibited

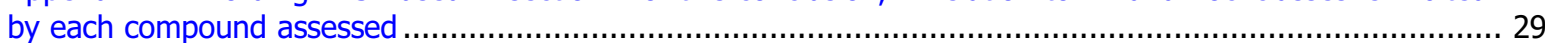

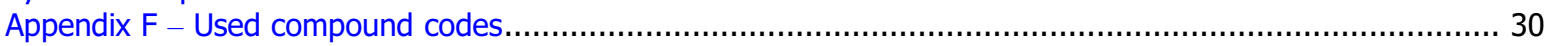




\section{Background}

Commission Implementing Regulation (EU) No $844 / 2012^{1}$, as amended by Commission Implementing Regulation (EU) No $2018 / 1659^{2}$ (hereinafter referred to as 'the Regulation'), lays down the provisions for the procedure of the renewal of the approval of active substances, submitted under Article 14 of Regulation (EC) No 1107/20093. This regulates for the European Food Safety Authority (EFSA) the procedure for organising the consultation of Member States, the applicant(s) and the public on the initial evaluation provided by the rapporteur Member State (RMS) and/or co-rapporteur Member State (co-RMS) in the renewal assessment report (RAR), and the organisation of an expert consultation where appropriate.

In accordance with Article 13 of the Regulation, unless formally informed by the European Commission that a conclusion is not necessary, EFSA is required to adopt a conclusion on whether the active substance can be expected to meet the approval criteria provided for in Article 4 of Regulation (EC) No 1107/2009 within 5 months from the end of the period provided for the submission of written comments, subject to an extension of an additional 3 months where additional information is required to be submitted by the applicant(s) in accordance with Article 13(3). Furthermore, in accordance with Article 13(3a), where the information available in the dossier is not sufficient to conclude the assessment on whether the approval criteria for endocrine disruption are met, additional information can be requested to be submitted in a period of minimum 3 months, not exceeding 30 months, depending on the type of information requested.

In accordance with Article 1 of the Regulation, the RMS, Poland, and co-RMS, France, received an application from K-I Chemical Europe SA/NV for the renewal of approval of the active substance benthiavalicarb. Complying with Article 8 of the Regulation, the RMS checked the completeness of the dossier and informed the applicant, the co-RMS (France), the European Commission and EFSA about the admissibility.

The RMS provided its initial evaluation of the dossier on benthiavalicarb (variant assessed benthiavalicarb-isopropyl) in the RAR, which was received by EFSA on 31 October 2017 (Poland, 2017).

In accordance with Article 12 of the Regulation, EFSA distributed the RAR to the Member States and the applicant, K-I Chemical Europe SA/NV, for consultation and comments on 9 March 2018. EFSA also provided comments. In addition, EFSA conducted a public consultation on the RAR. EFSA collated and forwarded all comments received to the European Commission on 15 May 2018. At the same time, the collated comments were forwarded to the RMS for compilation and evaluation in the format of a reporting table. The applicant was invited to respond to the comments in column 3 of the reporting table. The comments and the applicant's response were evaluated by the RMS in column 3.

The need for expert consultation and the necessity for additional information to be submitted by the applicant in accordance with Article 13(3) of the Regulation were considered in a telephone conference between EFSA and the RMS on 29 June 2018. On the basis of the comments received, the applicant's response to the comments and the RMS's evaluation thereof, it was concluded that additional information should be requested from the applicant, and that EFSA should conduct an expert consultation in the areas of mammalian toxicology, residues, environmental fate and behaviour and ecotoxicology.

In addition, in accordance with the provisions of Commission Implementing Regulation (EU) No 2018/1659, following a consultation with Member States in the Pesticides Peer Review Experts' Meeting 186 (mammalian toxicology, November 2018) followed by the Pesticide Peer Review Experts' Teleconference 203 (January 2019), the applicant was given the opportunity to submit, within a period of 3 months, additional information to address the approval criteria set out in point 3.6 .5 and/or point

\footnotetext{
${ }^{1}$ Commission Implementing Regulation (EU) No 844/2012 of 18 September 2012 setting out the provisions necessary for the implementation of the renewal procedure for active substances, as provided for in Regulation (EC) No 1107/2009 of the European Parliament and of the Council concerning the placing of plant protection products on the market. OJ L 252, 19.9.2012, p. 26-32.

2 Commission Implementing Regulation (EU) No 2018/1659 of 7 November 2018 amending Implementing Regulation (EU) No $844 / 2012$ in view of the scientific criteria for the determination of endocrine-disrupting properties introduced by Regulation (EU) 2018/605.

3 Regulation (EC) No 1107/2009 of 21 October 2009 of the European Parliament and of the Council concerning the placing of plant protection products on the market and repealing Council Directives 79/117/EEC and 91/414/EEC. OJ L 309, 24.11.2009, p. $1-50$.
} 
3.8.2 of Annex II to Regulation (EC) No 1107/2009, as amended by Commission Regulation (EU) $2018 / 605^{4}$, and/or documentary evidence demonstrating that benthiavalicarb-isopropyl may be used such that exposure is negligible, or the conditions for the application of the derogation under Art. 4(7) of Regulation (EC) No 1107/2009 are met. Subsequently, the applicant provided further information aimed at demonstrating that the exposure of humans to benthiavalicarb-isopropyl was negligible under realistic conditions of use. Benthiavalicarb-isopropyl has therefore been assessed under the provisions of negligible exposure to satisfy point 3.6.5 of Annex II of Regulation 1107/2009. Furthermore, the applicant requested a derogation under Article 4(7) of Regulation (EC) 1107/2009, submitting evidence regarding the necessity of benthiavalicarb-isopropyl to control a serious danger to plant health. The evaluation of the relevant data is presented in the Appendices $C$ and $D$ to this conclusion. A public consultation on the draft Art 4(7) scientific report and the revised RAR on the endocrine and negligible exposure assessments made available after the 3-month clock stop was conducted in July-September 2020. All comments received, including from the applicant and Member States, were collated in the format of a commenting table (on the draft Art 4(7) scientific report) and reporting table (on the revised RAR on the assessment of the endocrine-disrupting properties and negligible exposure assessment).

The outcome of the telephone conference, together with EFSA's further consideration of the comments, is reflected in the conclusions set out in column 4 of the reporting table. All points that were identified as unresolved at the end of the comment evaluation phase and which required further consideration, including those issues to be considered in an expert consultation, were compiled by EFSA in the format of an evaluation table.

The conclusions arising from the consideration by EFSA, and as appropriate by the RMS, of the points identified in the evaluation table, together with the outcome of the expert consultation and the written consultation on the assessment of additional information, where these took place, were reported in the final column of the evaluation table.

A final consultation on the conclusions arising from the peer review of the risk assessment, including the negligible exposure assessment and the evaluation of the data regarding the necessity of benthiavalicarb-isopropyl to control a serious danger to plant health which cannot be contained by other available means, took place with Member States via a written procedure in June-July 2021.

This conclusion report summarises the outcome of the peer review of the risk assessment of the active substance and the representative formulation, evaluated on the basis of the representative use of as a fungicide on potato (field use), as proposed by the applicant. In accordance with Article 12(2) of Regulation (EC) No 1107/2009, risk mitigation options identified in the RAR and considered during the peer review, if any, are presented in the conclusion.

In addition, the peer review also provided considerations on whether exposure to humans and the environment from the representative uses of benthiavalicarb-isopropyl can be considered negligible, taking into account the European Commission's draft guidance on this topic. An evaluation of data concerning the necessity of benthiavalicarb-isopropyl as a fungicide to control a serious danger to plant health which cannot be contained by other available means, including non-chemical methods is also presented (see Appendices C and D).

A list of the relevant end points for the active substance and the formulation is provided in Appendix B. In addition, the considerations as regards the cut-off criteria for benthiavalicarb-isopropyl according to Annex II of Regulation (EC) No 1107/2009 are summarised in Appendix A.

A key supporting document to this conclusion is the peer review report (EFSA, 2021), which is a compilation of the documentation developed to evaluate and address all issues raised in the peer review, from the initial commenting phase to the conclusion. The peer review report comprises the following documents, in which all views expressed during the course of the peer review, including minority views, where applicable, can be found:

- the comments received on the RAR;

- the reporting tables (26 June 2018 and 12 November $2020^{5}$ );

- the evaluation table (June 2021);

- the reports of the scientific consultation with Member State experts (where relevant);

- the comments received on the assessment of the additional information (where relevant);

\footnotetext{
${ }^{4}$ Commission Regulation (EU) 2018/605 of 19 April 2018 amending Annex II to Regulation (EC) No 1107/2009 by setting out scientific criteria for the determination of endocrine disrupting properties. OJ L 101, 20.4.2018, p. 33-36.

${ }^{5}$ Reporting table following consultation on the revised RAR on the assessment of the endocrine-disrupting properties and negligible exposure assessment made available after the 3-month clock stop.
} 
- $\quad$ the comments received on the draft EFSA conclusion.

Given the importance of the RAR, including its revisions (Poland, 2021), and the peer review report, both documents are considered as background documents to this conclusion and thus are made publicly available.

It is recommended that this conclusion and its background documents would not be accepted to support any registration outside the EU for which the applicant has not demonstrated that it has regulatory access to the information on which this conclusion report is based.

\section{The active substance and the formulated product}

Benthiavalicarb is the ISO common name for $[(1 S)-1-\{[(1 R)-1-(6-$ fluoro-1,3-benzothiazol-2-yl)ethyl $]$ carbamoyl\}-2-methylpropyl]carbamic acid (IUPAC). It should be noted that the evaluated data belong to benthiavalicarb-isopropyl, a derivative of benthiavalicarb. Benthiavalicarb-isopropyl is the modified ISO common name for isopropyl $[(S)-1-\{[(1 R)-1$-(6-fluoro-1,3-benzothiazol-2-yl)ethyl $]$ carbamoyl $\}$-2methylpropyl]carbamate.

The representative formulated product for the evaluation was 'KIF-230 15\% WG', a waterdispersible granule (WG) containing $150 \mathrm{~g} / \mathrm{kg}$ benthiavalicarb-isopropyl.

The representative use evaluated comprises field applications by spraying with tractor-mounted equipment as a fungicide on potato against late blight (Phytophthora infestans) in the central EU regulatory zone (CEU). Full details of the GAP can be found in the list of end points in Appendix $B$.

Data were submitted to conclude that the use of benthiavalicarb-isopropyl according to the representative use proposed at CEU level results in a sufficient fungicidal efficacy against late blight, following the guidance document SANCO/2012/11251-rev. 4 (European Commission, 2014b).

\section{Conclusions of the evaluation}

\section{Identity, physical/chemical/technical properties and methods of analysis}

The following guidance documents were followed in the production of this conclusion (European Commission, 2000a,b, 2010).

The proposed minimum purity specification for benthiavalicarb-isopropyl was based on batch data from industrial scale production and, for impurities, on quality control data. The proposed specification of the active substance as manufactured is min. $930 \mathrm{~g} / \mathrm{kg}$. EFSA notes that based on the renewal data, the minimum purity could have been increased for this renewal. Toluene was considered as a relevant impurity with maximum specification of $1 \mathrm{~g} / \mathrm{kg}$ (see Section 2). Based on the renewal batch data and the changes in the relevant impurity profile, it is proposed to update the reference specification to the specification proposed by the RMS (see reference specification in the Appendix B). The batches used in the (eco)toxicological assessment do not fully support the original reference and the newly proposed reference specification (see data gaps in Sections 2 and 5). An FAO specification does not exist for benthiavalicarb-isopropyl.

The main data regarding the identity of benthiavalicarb-isopropyl and its physical and chemical properties are given in Appendix B.

Adequate methods are available for the generation of pre-approval data required for the risk assessment. Methods of analysis are available for the determination of the active substance and the relevant impurity toluene in the technical material and in the representative formulation.

The residue definition for monitoring in food and feed of plant origin was defined as benthiavalicarb-isopropyl (KIF-230R-L), its diastereomer (KIF-230S-L) and their respective enantiomers (KIF-230S-D and -R-D), expressed as benthiavalicarb-isopropyl. The compounds of the residue definition can be monitored in food and feed of plant origin by the multi-residue method DFG S19 with reverse phase high-performance liquid chromatography with tandem mass spectroscopy (HPLC-MS/MS) with limits of quantification (LOQs) of $0.01 \mathrm{mg} / \mathrm{kg}$ for each analyte (KIF-230R-L and -S-L) in all commodity groups. Pending on the final residue definition for monitoring in food and feed of animal origin additional analytical methods might be required.

The residue definition for monitoring in the environmental matrices was defined as benthiavalicarbisopropyl (KIF-230R-L). Reverse phase HPLC-MS/MS methods were proposed for monitoring benthiavalicarb-isopropyl in the environmental matrices with LOQs of $0.01 \mathrm{mg} / \mathrm{kg}$ in soil, $0.05 \mu \mathrm{g} / \mathrm{L}$ in drinking water and surface water and $0.75 \mu \mathrm{g} / \mathrm{m}^{3}$ in air. 
Benthiavalicarb-isopropyl (KIF-230R-L) and its diastereomer (KIF-230S-L) were defined as residue definition for monitoring in body fluids and tissues. Reverse phase HPLC-MS/MS method is available for monitoring the compounds of the residue definition with LOQs of $0.05 \mathrm{mg} / \mathrm{L}$ for body fluids and $0.01 \mathrm{mg} / \mathrm{kg}$ in animal tissues for each analyte. Based on the fact that none of the proposed monitoring methods are enantioselective, it is not possible to distinguish between the enantiomers. Therefore, the methods determine all four possible isomers, but the pair of enantiomers only as a sum, i.e. (KIF-230RL + KIF-230S-D) expressed as KIF-230R-L and (KIF-230S-L+ KIF-230R-D) expressed as KIF-230S-L.

\section{Mammalian toxicity}

The following guidance documents were followed in the production of this conclusion (European Commission, 2003, 2012; EFSA 2014; EFSA PPR Panel, 2012; ECHA and EFSA, 2018) and draft Technical Guidance Document on assessment of negligible exposure (European Commission, 2015).

Benthiavalicarb-isopropyl was discussed at the Pesticides Peer Review Experts' Meeting 186 in November 2018 and at the Peer Review Experts' Teleconferences TC 203 in January 2019 and TC 44 in March 2021.

It should be noted that the evaluated toxicological data belong to benthiavalicarb-isopropyl.

The analytical profile of the batches used in toxicological studies was not fully compliant with the technical specifications provided (from the first peer review and the one proposed for renewal) resulting in an issue not finalised. For two impurities, the levels proposed in the specifications are not covered by toxicological batches and their toxicological relevance cannot be concluded (data gap, see Section 9.1). Toluene was considered a toxicologically relevant impurity (harmonised classification Repr. Cat.2 - H361d according to Reg $1272 / 2008^{6}$ ); however, at the level specified in the new proposed technical specification $(1 \mathrm{~g} / \mathrm{kg})$, toluene does not pose a concern. The analytical methods used in toxicological studies were overall considered fit for purpose (see Section 1).

Benthiavalicarb-isopropyl is extensively and rapidly absorbed after oral administration and it is widely distributed, mainly in the gastro-intestinal tract, bile duct, urinary bladder, liver and kidney. Metabolism is extensive after low-dose administrations and limited following high-dose administrations; the predominant routes of metabolism are by glutathione conjugation or by hydroxylation on the benzene or valyl moieties. Rapid and quite extensive excretion is predominantly via faeces. In vitro comparative metabolism studies were not provided; therefore, identification of human unique metabolites and the assessment of the adequateness of the tested animal species for the toxicological assessment could not be concluded (data gap and issue not finalised, see Section 9.1). The residue definition for body fluids and tissues should include benthiavalicarb-isopropyl (KIF-230R-L) and its diastereoisomer (KIF-230S- $L$ ) for the purpose of human biomonitoring.

Benthiavalicarb-isopropyl has a low acute toxicity after oral, dermal and inhalation administration. It is neither a skin nor an eye irritant, while according to the peer review, it may meet the criteria to be classified as a skin sensitiser (Cat. 1B, H317).

No phototoxicity studies were provided since benthiavalicarb-isopropyl absorbs only at $\lambda 292.5 \mathrm{~nm}$ and does not show any absorption at $\lambda>300 \mathrm{~nm}$. It is noted, however, that phototoxicity testing applying the new version of the OECD TG 432 (June, 2019) would allow for a proper assessment of UVB absorbers (data gap, see Section 10).

In short-term studies, the rat was considered the most sensitive species and the overall shortterm toxicity no observed adverse effect level (NOAEL) is $14.1 \mathrm{mg} / \mathrm{kg}$ body weight (bw) per day, based on anaemia, liver effects (hepatocyte hypertrophy, increased absolute and relative liver weight) and related changes in clinical chemistry parameters observed at $353 \mathrm{mg} / \mathrm{kg}$ bw per day in the 90-day rat dietary study.

Benthiavalicarb-isopropyl was tested for its genotoxic potential using a battery of in vitro tests (bacterial reverse mutation test, mammalian chromosome aberration test, mammalian cell gene mutation test, unscheduled DNA synthesis test and comet assay) and in vivo tests (mammalian erythrocyte micronucleus test, unscheduled DNA synthesis test and transgenic rodent gene mutation assay): all test results were negative apart from two positive results with two lots of technical grade benthiavalicarb-isopropyl (KIF-230 TG) in the TA98 strain of Salmonella typhimurium in the presence of metabolic activation. However, further studies demonstrated that these positive results were not due to the active substance but due to impurities. Although present at effective levels in the two test batches,

\footnotetext{
${ }^{6}$ Regulation (EC) No 1272/2008 of the European Parliament and of the Council of 16 December 2008 on classification, labelling and packaging of substances and mixtures, amending and repealing Directives 67/548/EEC and 1999/45/EC, and amending Regulation (EC) No 1907/2006. OJ L 353, 31.12.2008, p. 1-1355.
} 
a recent analysis of current industrial-scale production batches indicated that these mutagenic impurities are not detectable in technical grade benthiavalicarb-isopropyl. Therefore, benthiavalicarbisopropyl is unlikely to be genotoxic.

In long-term studies in rodents, benthiavalicarb-isopropyl showed non-neoplastic findings in liver (e.g. increased organ weight, histopathological findings, changes in clinical chemistry parameters), kidney (histopathological findings) and thyroid (histopathological findings) whereas neoplastic findings were observed in liver (hepatocellular adenoma) and uterus (adenocarcinoma) in rats, and in liver (hepatocellular adenoma/carcinoma, hepatoblastoma) and thyroid (follicular cell adenoma) in mice. The relevant systemic long-term NOAEL is $9.9 \mathrm{mg} / \mathrm{kg}$ bw per day based on effects in liver (changes in clinical chemistry parameters such as gamma glutamyl transferase (GGT), free and total cholesterol and phospholipids, increased absolute and relative liver weight, hepatocellular hypertrophy, fatty changes, foci of cellular alteration and spongiosis), kidney (increased absolute and relative kidney weight, glomerulo-sclerosis, chronic nephropathy and tubular dilation in males) observed in the longterm toxicity and carcinogenicity study in rats at $249.6 \mathrm{mg} / \mathrm{kg}$ bw per day. The carcinogenicity NOAEL in rat is $9.9 \mathrm{mg} / \mathrm{kg}$ bw per day based on increased incidence of hepatocellular tumours in males (hepatocellular adenoma) and uterine tumours in females (adenocarcinoma) and has the same value of systemic NOAEL. A phenobarbital-like mode of action for liver tumours (involving the induction of hepatic enzymes through constitutive androstane receptor (CAR) activation) was discussed at the

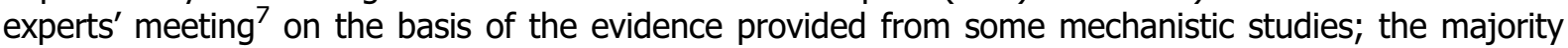
of the experts considered that, although this mode of action (MoA) could explain also the formation of thyroid tumours in mice, other molecular initiating events (MIEs) could be implicated in the tumorigenic process for liver neoplasms and not investigated in the data set (e.g. sodium iodide symporter - NIS - inhibition, competition with transporter proteins for thyroid hormones, $\beta$-catenin pathway combined with CAR activation, etc.). In addition, the experts agreed that the MoA for the induction of liver tumours can be considered not sufficiently investigated (only few key events in the MoA analysis were characterised) and the non-human relevance was considered not sufficiently demonstrated (no in vivo test was performed with knock out animals). The RMS disagreed. A dopamine receptor agonist-like mechanism (causing changes in oestradiol/progesterone ratio in the ageing rats) was also discussed as a possible MoA for uterine tumours and considered by the RMS not relevant for humans; however, the majority of experts considered that this mechanism is not the only MoA that can explain such findings in the uterus. In addition, uterus adenoma (one animal affected per each dose level starting from the mid dose) and uterus adenocarcinoma (1 single animal affected at the high dose only) were observed also in the mouse long-term toxicity and carcinogenicity study: The experts indicated that uterine adenocarcinoma is considered a quite rare finding in the mouse.

Since the neoplasms in uterus and liver were considered treatment-related and were observed in two different species and relevance for humans could not be excluded, the majority of experts agreed that criteria for classification as carcinogen Cat. 1B (H350) according to Regulation (EC) No 1272/2008 might be met for benthiavalicarb-isopropyl (critical area of concern); a minority of the experts (including the RMS) considered that category 2 classification would be more appropriate. It is noted that a CLH report that proposed classification as a category 2 carcinogen based on uterine adenocarcinoma incidence observed in rats was made available on ECHA website (CLH Report, January 2021). ${ }^{8}$

Benthiavalicarb-isopropyl did not show reproductive toxicity potential in rats: The relevant parental NOAEL was set at $10 \mathrm{mg} / \mathrm{kg}$ bw per day, based on increased absolute and relative liver weight and slight hepatocyte hypertrophy at $99.7 \mathrm{mg} / \mathrm{kg}$ bw per day in F1 males; the offspring NOAEL was set at $67.2 \mathrm{mg} / \mathrm{kg}$ bw per day on the basis of increased absolute and relative liver weight and decreased absolute and relative thymus and spleen weights at $702.5 \mathrm{mg} / \mathrm{kg}$ bw per day; the reproductive toxicity NOAEL was $702.5 \mathrm{mg} / \mathrm{kg}$ bw per day (highest dose tested).

In the rat developmental toxicity study, the maternal NOAEL was set at $10 \mathrm{mg} / \mathrm{kg}$ bw per day based on increased absolute and relative liver and adrenal weights at $100 \mathrm{mg} / \mathrm{kg}$ bw per day; the NOAEL for developmental toxicity was $100 \mathrm{mg} / \mathrm{kg}$ bw per day based on the slight increased incidence of some visceral malformations at $1,000 \mathrm{mg} / \mathrm{kg}$ bw per day. In the rabbit developmental toxicity study, the maternal NOAEL was set at $20 \mathrm{mg} / \mathrm{kg}$ bw per day, based upon abortions and increase in liver weight at $40 \mathrm{mg} / \mathrm{kg}$ bw per day; fetal NOAEL was set at $20 \mathrm{mg} / \mathrm{kg}$ bw per day based on skeletal retardation in fetuses at $40 \mathrm{mg} / \mathrm{kg}$ bw per day. During the Pesticide Peer Review Experts' Meeting 186,

\footnotetext{
7 Please refer to the Pesticide Peer Review Experts' Meeting 186 (discussion point 2.1) (EFSA, 2021).

${ }^{8}$ Available online: www.echa.europa.eu and https://echa.europa.eu/documents/10162/07ad73f0-8d62-6bd6-3ce1-cc84ea5427c3
} 
the increased incidence of dwarfism observed at the highest dose was concluded to be treatment related and likely to result from maternal toxicity. As regards incomplete ossification of the hindlimb talus, the experts agreed that maternal toxicity could not explain such a finding. ${ }^{9}$ Based on these findings, criteria for classification for developmental effects according to Regulation (EC) 1272/2008 are unlikely to be met.

Neurotoxicity was assessed in an acute and a subacute neurotoxicity study. In the acute oral neurotoxicity study in rats, decreased motor activity was observed after the administration of $2,000 \mathrm{mg} / \mathrm{kg}$ bw in both sexes (statistically significant in males and below historical control data); a statistically significant decrease in motor activity was also noted in the subacute study at the top dose in males $(1,853.7 \mathrm{mg} / \mathrm{kg}$ bw per day), on week 4 . The majority of the experts agreed that it cannot be excluded that the effect on motor activity is related to treatment, and thus, the acute neurotoxicity lowest observable adverse effect level (LOAEL) was set at $2,000 \mathrm{mg} / \mathrm{kg}$ bw; the RMS disagreed. ${ }^{10}$

Metabolites KIF-230-M-1, KIF-230-M-4 and KIF-230-M-5 are metabolites for which consumer exposure (processed commodities) is expected, and therefore, toxicological assessment is needed. KIF-230-M-1 showed acute toxicity $\left(L D_{50}=467-545 \mathrm{mg} / \mathrm{kg}\right.$ bw) and no potential to induce gene mutation in bacteria (Ames test negative in the presence and absence of metabolic activation). KIF-230-M-4 did not show acute toxicity $\left(\mathrm{LD}_{50}>2,000 \mathrm{mg} / \mathrm{kg} \mathrm{bw}\right)$ and the Ames test was positive with S9 mixture (strain TA98). KIF-230-M-5 showed acute toxicity $\left(L_{50}=545-605 \mathrm{mg} / \mathrm{kg} \mathrm{bw}\right)$ and the Ames test showed negative results in the presence and absence of metabolic activation. However, in the absence of the evaluation of gene mutation in mammalian cells, clastogenicity and aneugenicity potential and general toxicity, the toxicological profile for these three metabolites cannot be concluded (data gap and issue not finalised, see Sections 3 and 9.1).

The issue of isomeric conversion of benthiavalicarb-isopropyl from $R-L$ to $S$ - $L$ observed in processed commodities and metabolism studies in grapes might raise the need to address the respective toxicity profile of the isomers, since the data available on the $S$ - $L$ isomer (acute oral toxicity study and Ames test) are not sufficient to conclude that the $S-L$ isomer is not more toxic than the parent ( $R-L$ isomer). For the representative use additional data are not needed, since there is no isomeric conversion observed in potatoes; however, it should be reconsidered for other uses (e.g. authorised uses) where isomeric conversion is observed (see Section 3).

The experts agreed that benthiavalicarb-isopropyl is unlikely to be immunotoxic and the effects observed mainly in the 90-day studies in rats, mice and dogs and in the 1-year dog study (anaemia, increase in globulins and decrease in thymus weight) are considered secondary to liver toxicity.

The acceptable daily intake (ADI) is established at $0.1 \mathrm{mg} / \mathrm{kg}$ bw per day, based on the 2-year rat study (NOAEL of $9.9 \mathrm{mg} / \mathrm{kg}$ bw per day and applying an uncertainty factor (UF) of 100). The same ADI was agreed during the previous evaluation of the substance (EFSA, 2007; European Commission, 2008). The acute reference dose (ARfD) is set at $6.7 \mathrm{mg} / \mathrm{kg}$ bw based on the acute neurotoxicity study in the rat (LOAEL of $2000 \mathrm{mg} / \mathrm{kg}$ bw and applying an UF of 300 to account for the lack of a NOAEL). It is noted that no ARfD was set during the previous assessment. The acceptable operator exposure level (AOEL) is set at $0.1 \mathrm{mg} / \mathrm{kg}$ bw per day based on maternal toxicity (increased adrenal and liver weights) observed in the developmental toxicity study in the rat (NOAEL $10 \mathrm{mg} / \mathrm{kg}$ bw per day) and applying an UF of 100 with no correction for oral absorption. The same AOEL was agreed during the previous evaluation of the substance. The acute AOEL (AAOEL) is set at $6.7 \mathrm{mg} / \mathrm{kg} \mathrm{bw}$ (same value as ARfD).

For the representative use on potatoes, the predicted exposure levels for operators, workers, residents and bystanders are below the (A)AOEL without the use of personal protective equipment or other mitigation measures. As first-tier approach for the assessment of negligible exposure according to the available draft guidance (European Commission, 2015), the predicted exposure levels are all below $10 \%$ of the (A)AOEL for all groups (operators, workers, bystanders and residents). As second-tier approach, the margin of exposure with regard to the critical effect (NOAEL for carcinogenicity of $9.9 \mathrm{mg} / \mathrm{kg}$ bw per day) is higher than 1,000 for all groups (see Appendix B). It is noted that the worker exposure estimate is refined with experimental DFR and DT 50 values.

\footnotetext{
${ }^{9}$ For full details on the experts' discussion, please refer to experts' consultation point 2.2 of the Pesticides Peer Review Experts' Meeting 186 in November 2018 (EFSA 2021).

${ }^{10}$ For full details on the experts' discussion, please refer to experts' consultation point 2.3 of the Pesticides Peer Review Experts' Meeting 186 in November 2018 (EFSA 2021).
} 


\section{Residues}

The assessment in the residue section is based on the following guidance documents (OECD, 2009, 2011; European Commission, 2011; JMPR, 2004, 2007).

Benthiavalicarb-isopropyl was discussed at the Pesticides Peer Review Experts' Meeting 187 in November 2018.

Primary crop metabolism of benthiavalicarb-isopropyl (KIF-230R-L) labelled at benzyl ring and Lvalyl side chain has been investigated in fruits (grapes, tomatoes) by foliar applications and in root crops (potatoes) by foliar and soil applications. KIF-230R- $L$ was the major compound in grapes (up to $97 \%$ total radioactive residue (TRR)), tomatoes (up to 95\% TRR) and potato foliage (up to $90 \%$ TRR). In mature potato tubers, the TRR was very low $(0.014 \mathrm{mg} / \mathrm{kg}$ ) with KIF- $230 R-L$ accounting for $4.7 \%$ TRR. Two unknown metabolites accounting for up to $40 \%$ of the TRR but individually less than $10 \%$ TRR in tubers were suggested to be benzene-hydroxylated compounds and sugar conjugates of KIF-230R- $L$ after further analysis. The conjugated form of KIF-230R- $L$ was found also in tomato fruits in lower amount compared to the parent.

The chiral analysis performed in the metabolism studies in potatoes and grapes showed that no isomeric conversion of KIF-230R- $L$ into $S-L, R-D$ and $S-D$ isomers occurred in potato foliage, while in grapes, KIF-230S- $L$ presented $10-20 \%$ of the KIF-230R- $L$ isomer level. This stereoisomeric conversion of KIF-230R-L into KIF-230S- $L$ in grapes was confirmed in the field trials. In tomato metabolism studies, isomeric conversion was not observed although in field trial samples analysed before processing, the KIF-230S-L level was $5 \%$ of KIF-230R-L.

Based on the available data, the proposed residue definition for monitoring and risk assessment in primary fruits and root crops is 'benthiavalicarb-isopropyl (KIF-230R-L), its diastereomer (KIF-230S-L) and their respective enantiomers (KIF-230S-D and KIF-230R$D)$, expressed as benthiavalicarb-isopropyl'. The proposed residue definitions only cover the fruits and root crop groups.

Rotational crops metabolism studies were not available though triggered. Two field rotational trials on lettuce, carrot and barley conducted at a lower dose rate compared to the representative GAP (see details in Appendix B) analysed for KIF-230R-L, S- $L$ isomer and the relevant soil metabolites KIF-230M-1, KIF-230-M-4, KIF-230-M-5 were provided. The samples were not fully acceptable since they were analysed within the time interval for which the stability of KIF-230-M-1, KIF-230-M-4 and KIF-230-M-5 was not demonstrated; besides, their genotoxic and general toxicity profile was also not addressed (see data gap in Section 2). Since the rotational crop trials were underdosed and the residues in the soil at planting were limited, a bridging study comparing the plant uptake of the parent and the relevant soil metabolites KIF-230-M-1, KIF-230-M-4 and KIF-230-M-5 is needed (data gap and issue not finalised, see Section 9.1). In case of 'preferential metabolites' uptake, further rotational crops studies ensuring sufficiently high concentration of these compounds in the soil will be triggered. With the available data residue definitions for rotational crops were not proposed due to lack of data.

Sufficient residue field trials analysed for KIF-230R- $L$ and $S-L$ supported by validated analytical method showing the residue levels below $0.01 \mathrm{mg} / \mathrm{kg}$ were provided for the representative use in potatoes.

Stability of benthiavalicarb-isopropyl, its isomer $S$ - $L$ and the metabolites KIF-230-M-1, KIF-230-M-4 and KIF-230-M-5 during storage at $-18^{\circ} \mathrm{C}$ was demonstrated in different crop categories (see details in Appendix B).

In a hydrolysis study simulating conditions of pasteurisation, boiling/brewing/baking and sterilisation, benthiavalicarb-isopropyl was demonstrated as stable (94-97\%), the metabolite KIF-230M-4 found up to $3.7 \%$ applied radioactivity (AR) was explained as an impurity. Investigation of the isomeric conversion under hydrolysis and in processing trials showed different levels of the $S-L$ isomer between the studies on the nature and magnitude of residues (see also Evaluation Table data requirement point 3.7; EFSA, 2021). These differences were mainly linked to the variation of temperature, time and $\mathrm{pH}$ parameters. The residue definitions for processed commodities are the same as for primary crops.

Livestock and fish metabolism studies were not provided due to livestock exposure via the representative use being below $0.004 \mathrm{mg} / \mathrm{kg}$ bw per day. However, the fate and the uptake of the residues in rotational feed items was not elucidated; thus, further livestock assessment might be also needed. 
The requirement on the residue trials in honey and bee product was waived based on the justification of the applicant on non-attractiveness of potatoes to bees, which was considered acceptable.

The consumer risk assessment conducted with the EFSA PRIMo rev. 3.1 using an LOQ of $0.01 \mathrm{mg} / \mathrm{kg}$ for potato indicated that consumer exposure corresponds to $0.1 \%$ of the ADI and $0.05 \%$ of the ARfD. The estimates are provisional considering that the residue definitions for rotational crops (fate of residues and magnitude of the relevant metabolites) remain open including the livestock exposure assessment via rotational feed items.

While the toxicological profile of KIF-230S- $L$ was not addressed (see Section 2), the consumer risk assessment for the representative use is not affected since there is no isomeric conversion observed in potatoes but it should be reconsidered for other uses such as the authorised uses, where isomeric conversion is observed.

The consumer risk assessment from the consumption of drinking water is also not finalised due to the lack of information on the effect of water treatment processes on the nature of the residues, potentially present in surface water, when surface water is abstracted for drinking water (see Section 4).

As regards the negligible exposure assessment, according to the available draft Technical Guidance Document on assessment of negligible exposure (European Commission, 2015), the concentration of benthiavalicarb-isopropyl in potatoes was below the LOQ of $0.01 \mathrm{mg} / \mathrm{kg}$. However, the assessment of residues in rotational crops (fate and magnitude of residues) is not finalised, and therefore, residues in edible crops and feed items cannot be excluded. It is also noted that additional uses on onions, garlic, shallot, tomatoes and grapes not assessed under the renewal but authorised in Europe could lead to higher concentration of residues contributing to the consumer exposure.

\section{Environmental fate and behaviour} 2018.

Benthiavalicarb-isopropyl was discussed at the Pesticides Peer Review Experts' TC 199 in November

The rates of dissipation and degradation in the environmental matrices investigated were estimated using FOCUS (2006) kinetics guidance. In soil laboratory incubations under aerobic conditions in the dark, benthiavalicarb-isopropyl exhibited moderate persistence, forming the major $(>10 \% \mathrm{AR})$ metabolites KIF-230-M-1 (max. 27.7\% AR; low to medium persistence in soil), KIF-230-M-3 (max. $12.3 \% \mathrm{AR}$; low persistence in soil), KIF-230-M-4 (max. 9.8\% AR; moderate persistence in soil), KIF-230-M-5 (max. 26.8\% AR; low to high persistence in soil). Isomeric conversion of the active substance was not observed in any of the experiments. Mineralisation to carbon dioxide accounted for $4-12 \%$ AR after 120 days for the benzene ring ${ }^{14} \mathrm{C}$ radiolabel and for $45 \%$ AR after 120 days for the valyl moiety ${ }^{14} \mathrm{C}$ radiolabel. The formation of unextractable residues accounted for $22-58 \%$ AR after 120 days and for $36 \%$ AR after 120 days for the benzene and the valyl ${ }^{14} \mathrm{C}$ radiolabels, respectively. In anaerobic soil incubations, metabolite KIF-230-M-8 was measured up to $8.1 \%$ AR, and this metabolite is relevant only when prolonged anaerobic conditions are expected. Under aerobic conditions, metabolite KIF-230-M-8 exhibited low persistence in soil. Benthiavalicarb-isopropyl is not significantly photodegraded on the soil surface.

Benthiavalicarb-isopropyl and metabolites KIF-230-M-1 and KIF-230-M-3 exhibited medium mobility in soil. Metabolite KIF-230-M-4 exhibited high to medium soil mobility, metabolite KIF-230-M-5 exhibited low mobility and metabolite KIF-230-M-8 exhibited high soil mobility. It was concluded that the adsorption of benthiavalicarb-isopropyl and its soil metabolites was not $\mathrm{pH}$ dependent.

According to the data requirements, field soil dissipation investigations should be carried out for the parent active substance and metabolites when laboratory period required for $50 \%$ (DT50) or $90 \%$ (DT90) degradation are greater than 60 and 200 days, respectively. Therefore, analysis of the field study samples for metabolites KIF-230-M-5 and KIF-230-M-1 was triggered as the DT90 values for both metabolites resulted in higher than 200 days in laboratory studies, but this was not done. Therefore, a data gap was identified (see Section 10). However, the exposure assessment for the EU representative uses was completed using the available laboratory kinetic endpoints.

In laboratory incubations in dark aerobic natural sediment water systems, benthiavalicarb-isopropyl remained primarily in the water column. Metabolites KIF-230-M-1, KIF-230-M-3, KIF-230-M-4 and KIF-230-M-5 were formed in the sediment up to $5.1 \% A R, 26.3 \% A R, 22.7 \%$ AR and $11.9 \% A R$, respectively. 
The unextractable sediment fraction was the major sink for the benzene ring $14 \mathrm{C}$ radiolabel, accounting for $36-40 \%$ AR at study end (100 days). Mineralisation of this radiolabel accounted for $0.9-3.8 \%$ AR at the end of the study. The rate of decline of benthiavalicarb-isopropyl in a laboratory sterile aqueous photolysis experiment was slow relative to that occurred in the aerobic sediment water incubations. No chromatographically resolved component (excluding benthiavalicarb-isopropyl) accounted for $>5 \%$ AR.

The necessary surface water and sediment exposure assessments (predicted environmental concentrations (PEC) calculations) were carried out for the metabolites KIF-230-M-1, KIF-230-M-3, KIF-230-M-4, KIF-230-M-5 and KIF-230-M-8, using the FOCUS (FOCUS, 2001) step 1 approach (version 3.2 of the Steps 1-2 in FOCUS calculator). For the active substance benthiavalicarb-isopropyl, appropriate step 3 (FOCUS, 2001) was available. ${ }^{11}$ FOCUS Step 4 calculations were carried out in support of a negligible exposure assessment and appropriately followed the FOCUS (FOCUS, 2007) guidance, regarding no-spray drift buffer zones of up to $20 \mathrm{~m}$ being implemented for the drainage and run-off scenarios (representing a $59-93 \%$ spray drift reduction). The SWAN tool (version 5) was appropriately used to implement this spray drift mitigation in the simulations.

The necessary groundwater exposure assessments were appropriately carried out using FOCUS (European Commission, 2014a) scenarios and the models PEARL 4.4.4, PELMO 5.5.3 and MACRO 5.5.4. ${ }^{11}$ The potential for groundwater exposure from the representative uses by benthiavalicarbisopropyl and its metabolites above the parametric drinking water limit of $0.1 \mu \mathrm{g} / \mathrm{L}$ was concluded to be low in geoclimatic situations that are represented by all nine FOCUS groundwater scenarios.

The applicant did not provide appropriate information to address the effect of water treatment processes on the nature of the residues that might be present in surface water, when surface water is abstracted for drinking water. This has led to the identification of a data gap and results in the consumer risk assessment not being finalised (see Section 9.1).

The PEC in soil, surface water, sediment and groundwater covering the representative uses assessed can be found in Appendix B. A key to the persistence and mobility class wording used, relating these words to numerical DT and Koc endpoint values can be found in Appendix E.

\section{Ecotoxicology}

The risk assessment was based on the following documents: European Commission $(2002 a, b)$, SETAC (2001), EFSA (2009, 2013) and EFSA PPR Panel (2013).

Some aspects related to the risk assessment of benthiavalicarb were discussed at the Pesticides Peer Review Experts' teleconference 188 in November 2018.

The batches used in the ecotoxicological assessment do not fully support the original reference and the newly proposed reference specification (see also Sections 1 and 2) (data gap, see Section 10).

Acute and reproductive data were available with birds and mammals. Based on those data, a low acute and reproductive risk was concluded for all the relevant routes of exposure (dietary and through contaminated water) for the representative use in potatoes. No major metabolites ( $>10 \%$ TTR) were found in plants and, therefore, a dietary risk assessment was not performed with any metabolite. Low risk to pertinent (soil) metabolites was concluded when exposure through contaminated water is considered. A risk assessment through secondary poisoning was not triggered since neither benthiavalicarb-isopropyl nor its pertinent metabolites have a log Kow $\geq 3$.

Acute toxicity data with the active substance and the formulated product were available for fish and aquatic invertebrates. Chronic toxicity data with the active substance were available for fish, aquatic invertebrates and algae. The pertinent metabolites (KIF-230-M-1, KIF-230-M-3, KIF-230-M-4, KIF-230M-5 and KIF-230-M-8) were tested acutely for fish and invertebrates and chronically with algae.

Based on the available data, low acute and chronic risk to aquatic organisms for benthiavalicarbisopropyl was concluded by using FOCUS Step 2 PECsw for the representative use under assessment. Low risk was also concluded for the pertinent aquatic metabolites by using FOCUS Step 1 PECsw. It has to be noted that for the active substance, the lowest chronic endpoint for fish was derived from a prolonged toxicity test ( 21 days) with rainbow trout. The available study required by Regulation (EC) No $283 / 2013^{12}$, an early life stage (ELS) test performed with zebrafish, gave an endpoint five times higher. Some uncertainty was raised during the peer review as the prolonged toxicity test with the

\footnotetext{
${ }^{11}$ Simulations utilised the agreed Q10 of 2.58 (following EFSA, 2008) and Walker equation coefficient of 0.7.

12 Commission Regulation (EU) No 283/2013 of 1 March 2013 setting out the data requirements for active substances, in accordance with Regulation (EC) No 1107/2009 of the European Parliament and of the Council concerning the placing of plant protection products on the market. OJ L 93, 3.4.2013, p. 1-84.
} 
rainbow trout does not cover potential effects on reproduction and on early life stages of this species, while based on the available data, rainbow trout could be potentially more sensitive than zebrafish used in the ELS test. ${ }^{13}$ However, by considering that the endpoint for fish is the most conservative and by considering the high margin of safety in the risk assessment (low chronic risk concluded at FOCUS step 2), further vertebrate testing was considered unnecessary.

Acute (oral and contact) toxicity studies with honeybees were available with benthiavalicarbisopropyl and the representative formulation. Chronic oral study with adults and honeybee larvae were submitted with the formulated product and benthiavalicarb-isopropyl, respectively. Acute studies with the bumblebee Bombus terrestris and the representative formulation were also available. The risk to bees was assessed in line with the EFSA bee guidance document (EFSA, 2013). ${ }^{14} \mathrm{~A}$ low acute and chronic risk to honeybees and a low acute risk to bumblebees were indicated for the use of benthiavalicarb-isopropyl in potatoes at the screening step. Relevant plant metabolites were not identified; therefore, exposure to plant metabolites has not been considered further. A low risk from exposure to contaminated surface water was concluded for honeybee adults and larvae while a high risk via guttation fluid could not be excluded for larvae at the screening step. A further risk assessment was not available (data gap, see Section 10). The risk from exposure to contaminated puddle water was not evaluated (data gap, see Section 10). An assessment of accumulative effects was not available. Data were not available on sublethal effects, e.g. hypopharyngeal glands (data gap, see Section 10). Toxicity data and risk assessment were not provided for solitary bees.

For non-target arthropods (NTAs), toxicity studies with the representative formulation were conducted with the standard sensitive species, Aphidius rhopalosiphi and Typhlodromus pyri, and with two additional NTAs, Chrysoperla carnea and Poecilus cupreus. A low in- and off-field risk was concluded for the representative uses of benthiavalicarb-isopropyl.

Chronic toxicity studies with benthiavalicarb-isopropyl and the representative formulation were available for earthworms (the latter was considered only as supportive information). Based on the available data and risk assessment, a low risk was concluded for the representative use. Data on effects on soil macroorganisms other than earthworms were not required as a low risk to the relevant NTA species was concluded at tier 1 . A low risk to soil microorganisms was concluded for the representative use of benthiavalicarb-isopropyl. Toxicity data with the pertinent soil metabolite KIF230-M-1 were available for earthworms and soil microorganisms. The risk to the other metabolites, KIF-230-M-3, KIF-230-M-4, KIF-230-M-5 and KIF-230-M-8, was assessed assuming those metabolites to be 10 times more toxic than the parent compound. A low risk to all soil organisms was concluded for all the metabolites.

The risk to non-target terrestrial plants and organisms involved in sewage treatment processes was considered to be low for the representative use evaluated.

\section{Endocrine disruption properties}

The endocrine-disrupting properties of benthiavalicarb-isopropyl were discussed in several Peer Review Experts 'meetings (Pesticides Peer Review Experts' Meetings 186 and 188 in November 2018, TC 203 in January 2019 and TC 44 in April 2021).

With regard to the assessment of the endocrine disruption potential of benthiavalicarb-isopropyl for humans according to the ECHA/EFSA guidance (2018), the number and type of effects induced, and the magnitude and pattern of responses observed across studies were considered to determine whether benthiavalicarb-isopropyl interacts with the oestrogen, androgen and steroidogenesis (EAS) and thyroid ( $\mathrm{T}$ )-mediated pathways. Additionally, the conditions under which the effects occur were examined, in particular, whether or not endocrine-related responses occurred at dose(s) that also resulted in overt toxicity. This assessment, therefore, provides a weight-of-evidence analysis of the potential interaction of benthiavalicarb-isopropyl with the EAS and T signalling pathways using the available evidence in the data set.

The data set for the $\mathbf{T}$ modality was considered complete. There is evidence of a T-mediated pattern of adversity which was observed below the maximum tolerated dose (MTD) in the dog (increase in absolute and relative thyroid weight in the one-year study), in the rat at 1-year interim kill (thyroid follicular cell hyperplasia was observed at 52 weeks in the rat combined chronic and carcinogenicity study) and in female mice (thyroid follicular cell hyperplasia and adenoma) in the

\footnotetext{
13 See data requirement point 5.2. in the Evaluation Table (Peer Review Report, EFSA, 2021).

14 The acute risk assessment according to EC (2002) was added by EFSA in the LoEP.
} 
carcinogenicity study. When considering the pattern of the observed effects for T-mediated adversity and the pattern of changes in thyroid hormones (THs) and thyroid-stimulating hormone (TSH), benthiavalicarb induces hypothyroidism in the tested experimental species. Based on the available evidence, the ED criteria for T modality are considered met, leading to a critical area of concern.

The data set for the EAS modalities was not considered complete. However, EAS-mediated patterns of adversity were observed. Uterine adenocarcinoma was observed in the carcinogenicity study in rat in the presence of increased levels of circulating oestradiol; reduced number of corpora lutea in mouse (90-day study and carcinogenicity study) and ovary atrophy in the mouse carcinogenicity study; uterine angiectasis in the mouse carcinogenicity study and delay in sexual maturity in dog (90-day study). Changes in oestradiol and progesterone were only observed in the 2 -year rat study from week 26, possibly indicative of an unopposed oestrogen dominance. Based on the available evidence, the ED criteria for EAS modalities are considered met, leading to a critical area of concern.

The outcome of the assessment reported above for humans for EATS modalities does not apply to wild mammals as non-target organisms due to the following considerations:

- For the T modality, the identified adversity was based on changes in thyroid histopathology. No other more apical effects were observed in the available data set that could be attributed to the same Thyroid Mode of Action. Therefore, in line with the recommendations of the ECHA/ EFSA (2018) Guidance and common practice, effects at organ level were not considered relevant at the population level.

- For EAS modalities, the population relevance of the observed adversity in mammalian species could not be confirmed due to the uncertainty in the available data set and in the possible mode of action, e.g. a senescence-specific mode of action could not be excluded.

For non-target organisms other than mammals, neither the endocrine activity nor the endocrine adversity was sufficiently investigated. Additional data would be needed to draw a conclusion on the endocrine-disrupting properties of benthiavalicarb-isopropyl on non-target organisms for both T- and EAS-modalities, i.e. in the first instance, a test according to OECD Test Guideline 231 (Amphibian Metamorphosis Assay) and a test according to OECD TG 229 (Fish Short Term Reproduction Assay).

Based on the above considerations, the assessment of the endocrine-disrupting properties of benthiavalicarb-isopropyl for non-target organisms according to point 3.8 .2 of Annex II to Regulation (EC) No 1107/2009, as amended by Commission Regulation (EU) 2018/605 could not be concluded, leading to an issue not finalised (see Section 9.1). However, further data were not requested taking into account that benthiavalicarb-isopropyl was considered to meet the criteria for endocrine disruption for human health for the EATS modalities according to point 3.6.5 of Annex II of Regulation No 1107/2009, as amended by Commission Regulation (EU) 2018/605.

Regarding human health, considerations on negligible exposure are reported in Section 2 (mammalian toxicology) and Section 3 (residues) of this document.

Regarding the environment, the available PEC for benthiavalicarb-isopropyl in soil, surface water and sediment for all the representative uses assessed are above levels that can be routinely measured. ${ }^{15}$ There will be exposure of benthiavalicarb-isopropyl via food items of non-target organisms for the representative uses, as these organisms will enter fields on the same day an application is made.

\footnotetext{
${ }^{15}$ In line with the ethos of FAO/WHO (2009) further discussed in EFSA Scientific Committee (2012) and limits of analytical quantification needed for monitoring methods set out in European Commission (2021).
} 


\section{Overview of the risk assessment of compounds listed in residue definitions triggering assessment of effects data for the environmental compartments (Tables 1-4)}

Table 1: Soil

\begin{tabular}{l|l}
\hline Compound (name and/or code) & Ecotoxicology \\
\hline Benthiavalicarb-isopropyl & Low risk to soil organisms \\
\hline KIF-230-M-1 & Low risk to soil organisms \\
\hline KIF-230-M-3 & Low risk to soil organisms \\
\hline KIF-230-M-4 & Low risk to soil organisms \\
\hline KIF-230-M-5 & Low risk to soil organisms \\
\hline KIF-230-M-8 & Low risk to soil organisms \\
\hline
\end{tabular}

(a): Relevant only for prolonged anaerobic conditions.

Table 2: Groundwater ${ }^{(\mathrm{a})}$

\begin{tabular}{|c|c|c|c|c|c|}
\hline $\begin{array}{l}\text { Compound } \\
\text { (name } \\
\text { and/ } \\
\text { or code) }\end{array}$ & $\begin{array}{l}>0.1 \mu \mathrm{g} / \mathrm{L} \\
\text { at } 1 \mathrm{~m} \text { depth } \\
\text { for the } \\
\text { representative } \\
\text { uses }^{(\mathrm{b})} \\
\text { Step } 2\end{array}$ & $\begin{array}{l}\text { Biological } \\
\text { (pesticidal) } \\
\text { activity/ } \\
\text { relevance } \\
\text { Step 3a. }\end{array}$ & $\begin{array}{l}\text { Hazard identified } \\
\text { Steps } 3 b \text {. and } 3 c .\end{array}$ & $\begin{array}{l}\text { Consumer RA } \\
\text { triggered } \\
\text { Steps } 4 \text { and } 5\end{array}$ & $\begin{array}{l}\text { Human health } \\
\text { relevance }\end{array}$ \\
\hline $\begin{array}{l}\text { Benthiavalicarb- } \\
\text { isopropyl }\end{array}$ & No & Yes & - & - & Yes \\
\hline KIF-230-M-1 & No & Not triggered & $\begin{array}{l}\text { Not triggered. } \\
\text { Acutely toxic in the rat; } \\
\text { Ames test negative }\end{array}$ & No & $\begin{array}{l}\text { Not triggered for } \\
\text { the representative } \\
\text { uses assessed }\end{array}$ \\
\hline KIF-230-M-3 & No & Not triggered & $\begin{array}{l}\text { Not triggered. } \\
\text { Low acute oral toxicity } \\
\text { (rat); Ames test negative }\end{array}$ & No & $\begin{array}{l}\text { Not triggered for } \\
\text { the representative } \\
\text { uses assessed }\end{array}$ \\
\hline KIF-230-M-4 & No & Not triggered & $\begin{array}{l}\text { Not triggered. } \\
\text { Low acute oral toxicity in } \\
\text { the rat; Ames test } \\
\text { positive in the presence } \\
\text { of S9 }\end{array}$ & No & $\begin{array}{l}\text { Not triggered for } \\
\text { the representative } \\
\text { uses assessed }\end{array}$ \\
\hline KIF-230-M-5 & No & Not triggered & $\begin{array}{l}\text { Not triggered. } \\
\text { Acutely toxic in the rat; } \\
\text { Ames test negative }\end{array}$ & No & $\begin{array}{l}\text { Not triggered for } \\
\text { the representative } \\
\text { uses assessed }\end{array}$ \\
\hline KIF-230-M-8 ${ }^{(\mathrm{c})}$ & No & Not triggered & Not triggered. & No & $\begin{array}{l}\text { Not triggered for } \\
\text { the representative } \\
\text { uses assessed }\end{array}$ \\
\hline
\end{tabular}

(a): Assessment according to European Commission guidance of the relevance of groundwater metabolites (2003).

(b): FOCUS scenarios or relevant lysimeter.

(c): Relevant only for prolonged anaerobic conditions.

Table 3: Surface water and sediment

\begin{tabular}{l|l}
\hline Compound (name and/or code) & Ecotoxicology \\
\hline Benthiavalicarb-isopropyl & Low risk to aquatic organisms \\
\hline KIF-230-M-1 (from soil, water/sediment) & Low risk to aquatic organisms \\
\hline KIF-230-M-3 (from soil, water/sediment) & Low risk to aquatic organisms \\
\hline KIF-230-M-4 (from soil, water/sediment) & Low risk to aquatic organisms \\
\hline KIF-230-M-5 (from soil, water/sediment) & Low risk to aquatic organisms \\
\hline KIF-230-M-8 (from soil, relevant only for prolonged anaerobic conditions) & Low risk to aquatic organisms \\
\hline
\end{tabular}


Table 4: Air

Compound (name and/or code)

Toxicology

Benthiavalicarb-isopropyl

Rat $\mathrm{LD}_{50}$ inhalation $>4.6 \mathrm{mg} / \mathrm{L}$ air for $4 \mathrm{~h}$ (whole body)

\section{Particular conditions proposed to be taken into account by risk managers}

Risk mitigation measures (RMMs) identified following consideration of Member State (MS) and/or applicant's proposal(s) during the peer review, if any, are presented in this section. These measures applicable for human health and/or the environment leading to a reduction of exposure levels of operators, workers, bystanders/residents, environmental compartments and/or non-target organisms for the representative uses are listed below. The list may also cover any RMMs as appropriate, leading to an acceptable level of risks for the respective non-target organisms.

It is noted that final decisions on the need of RMMs to ensure the safe use of the plant protection product containing the concerned active substance will be taken by risk managers during the decisionmaking phase. Consideration of the validity and appropriateness of the RMMs remains the responsibility of MSs at product authorisation, taking into account their specific agricultural, plant health and environmental conditions at national level.

No particular conditions are proposed for the representative use evaluated.

\section{Concerns and related data gaps}

\subsection{Issues that could not be finalised}

An issue is listed as 'could not be finalised' if there is not enough information available to perform an assessment, even at the lowest tier level, for one or more of the representative uses in line with the uniform principles in accordance with Article 29(6) of Regulation (EC) No 1107/2009 and as set out in Commission Regulation (EU) No 546/2011 ${ }^{16}$ and if the issue is of such importance that it could, when finalised, become a concern (which would also be listed as a critical area of concern if it is of relevance to all representative uses).

An issue is also listed as 'could not be finalised' if the available information is considered insufficient to conclude on whether the active substance can be expected to meet the approval criteria provided for in Article 4 of Regulation (EC) No 1107/2009.

The following issues or assessments that could not be finalised have been identified, together with the reasons including the associated data gaps where relevant, which are reported directly under the specific issue to which they are related:

1) Compliance of the batches used in toxicological studies with the technical specifications could not be finalised (see Section 2).

a) Assessment of the toxicological relevance of two impurities was not available (relevant for the representative use evaluated; see Section 2).

2) Identification of unique human metabolites and adequateness of the animal species used for the toxicological assessment could not be concluded (see Section 2).

a) In vitro comparative metabolism studies were not available (relevant for the representative use evaluated; see Section 2).

3) The consumer dietary risk assessment could not be finalised since the residue definitions for rotational crops remain open including the livestock exposure assessment via rotational feed items (see Section 3).

a) A bridging study comparing the plant uptake of KIF-230R-L and the KIF-230-M-1, KIF-230-M-4 and KIF-230-M5 relevant soil metabolites to elucidate the risk assessment residue definition in rotational crops is not available. In case of 'preferential metabolites'

\footnotetext{
16 Commission Regulation (EU) No 546/2011 of 10 June 2011 implementing Regulation (EC) No 1107/2009 of the European Parliament and of the Council as regards uniform principles for evaluation and authorisation of plant protection products. OJ L $155,11.6 .2011$, p. 127-175.
} 
uptake, further rotational crops studies ensuring sufficiently high concentration of these compounds in the soil might be triggered (relevant for the representative uses in potatoes, see Section 3).

b) Further assessment of the toxicological profile (gene mutation in mammalian cells, clastogenicity and aneugenicity potential and general toxicity) of metabolites KIF-230-M-1, KIF-230-M-4 and KIF-230-M5, relevant for consumer exposure, was not available (relevant for the representative use in potatoes; see Sections 2 and 3).

4) The consumer risk assessment is not finalised with regard to the unknown nature of residues that might be present in drinking water consequent to water treatment processes following abstraction of surface water that might contain the active substance and its metabolites (see Sections 3 and 4).

a) Further data and information were not available to demonstrate that residues of benthiavalicarb-isopropyl will have no immediate or delayed harmful effects on human health, including that of vulnerable groups, or animal health, ...through drinking water (taking into account substances resulting from water treatment) (relevant to comply with the conditions of approval, not dependent of any specific use, see Section 4).

5) The assessment of the endocrine-disrupting properties of benthiavalicarb-isopropyl for nontarget organisms could not finalised for EATS modalities based on the available information (see Section 6).

\subsection{Critical areas of concern}

An issue is listed as a critical area of concern if there is enough information available to perform an assessment for the representative uses in line with the uniform principles in accordance with Article 29(6) of Regulation (EC) No 1107/2009 and as set out in Commission Regulation (EU) No 546/2011, and if this assessment does not permit the conclusion that, for at least one of the representative uses, it may be expected that a plant protection product containing the active substance will not have any harmful effect on human or animal health or on groundwater, or any unacceptable influence on the environment.

An issue is also listed as a critical area of concern if the assessment at a higher tier level could not be finalised due to lack of information, and if the assessment performed at the lower tier level does not permit the conclusion that, for at least one of the representative uses, it may be expected that a plant protection product containing the active substance will not have any harmful effect on human or animal health or on groundwater, or any unacceptable influence on the environment.

An issue is also listed as a critical area of concern if, in the light of current scientific and technical knowledge using guidance documents available at the time of application, the active substance is not expected to meet the approval criteria provided for in Article 4 of Regulation (EC) No 1107/2009.

The following critical areas of concern are identified, together with any associated data gaps, where relevant, which are reported directly under the specific critical area of concern to which they are related:

6) Carcinogenic potential observed in liver and uterus in two different species in the absence of sufficient demonstration of non-human relevance. Criteria for classification as category 1B might be met for benthiavalicarb-isopropyl; it is noted that a CLH proposal for classification as category 2 carcinogen was made available on ECHA website (January 2021) (relevant for the representative use evaluated; see Section 2).

7) Benthiavalicarb-isopropyl is considered to meet the criteria for endocrine disruption for humans for the T and EAS modalities according to point 3.6.5 of Annex II of Regulation No 1107/2009, as amended by Commission Regulation (EU) 2018/605 (see Section 6).

\subsection{Overview of the concerns identified for each representative use considered (Table 5)}

(If a particular condition proposed to be taken into account to manage an identified risk, as listed in Section 8, has been evaluated as being effective, then 'risk identified' is not indicated in Table 5)

In addition to the issues indicated below, benthiavalicarb-isopropyl is considered to meet the criteria for endocrine disruption for humans for the T and EAS modalities according to point 3.6.5 of Annex II of Regulation No 1107/2009, as amended by Commission Regulation (EU) 2018/605, whilst 
the assessment of the endocrine-disrupting properties for non-target organisms according to the scientific criteria for the determination of endocrine-disrupting properties as set out in point 3.8.2 of Annex II to Regulation (EC) No 1107/2009, as amended by Commission Regulation (EU) 2018/605, could not be finalised based on the available information. For the considerations as regards negligible exposure assessment, please refer to Sections 2, 3 and 6.

Table 5: Overview of concerns reflecting the issues not finalised, critical areas of concerns and the risks identified that may be applicable for some but not for all uses or risk assessment scenarios

\begin{tabular}{|c|c|c|}
\hline \multirow{2}{*}{\multicolumn{2}{|c|}{ Representative use }} & \multirow{2}{*}{$\begin{array}{l}\text { Potato } \\
\text { Spray application (F) }\end{array}$} \\
\hline & & \\
\hline \multirow[t]{2}{*}{ Operator risk } & Risk identified & \\
\hline & Assessment not finalised & \\
\hline \multirow[t]{2}{*}{ Worker risk } & Risk identified & \\
\hline & Assessment not finalised & \\
\hline \multirow[t]{2}{*}{ Resident/bystander risk } & Risk identified & \\
\hline & Assessment not finalised & \\
\hline \multirow[t]{2}{*}{ Consumer risk } & Risk identified & \\
\hline & Assessment not finalised & $x^{3,4}$ \\
\hline \multirow{2}{*}{$\begin{array}{l}\text { Risk to wild non-target terrestrial } \\
\text { vertebrates }\end{array}$} & Risk identified & \\
\hline & Assessment not finalised & \\
\hline \multirow{2}{*}{$\begin{array}{l}\text { Risk to wild non-target terrestrial } \\
\text { organisms other than vertebrates }\end{array}$} & Risk identified & \\
\hline & Assessment not finalised & \\
\hline \multirow[t]{2}{*}{ Risk to aquatic organisms } & Risk identified & \\
\hline & Assessment not finalised & \\
\hline \multirow{2}{*}{$\begin{array}{l}\text { Groundwater exposure to active } \\
\text { substance }\end{array}$} & Legal parametric value breached & \\
\hline & Assessment not finalised & \\
\hline \multirow{3}{*}{$\begin{array}{l}\text { Groundwater exposure to } \\
\text { metabolites }\end{array}$} & Legal parametric value breached ${ }^{(\mathrm{a})}$ & \\
\hline & Parametric value of $10 \mu \mathrm{g} / \mathrm{L}^{(\mathrm{b})}$ breached & \\
\hline & Assessment not finalised & \\
\hline
\end{tabular}

The superscript numbers relate to the numbered points indicated in Sections 9.1 and/or 9.2.

(a): When the consideration for classification made in the context of this evaluation under Regulation (EC) No 1107/2009 is confirmed under Regulation (EC) No 1272/2008 of the European Parliament and of the Council of 16 December 2008.

(b): Value for non-relevant metabolites prescribed in SANCO/221/2000-rev. 10 final, European Commission (2003).

\section{List of other outstanding issues}

Remaining data gaps not leading to critical areas of concern or issues not finalised but considered necessary to comply with the data requirements, and which are relevant for some or all of the representative uses assessed at EU level. Although not critical, these data gaps may lead to uncertainties in the assessment and are considered relevant.

These data gaps refer only to the representative uses assessed and are listed in the order of the sections:

- Phototoxicity study following appropriate protocol for UVB absorbers (e.g. according to the new version of the OECD TG 432, June, 2019) (relevant for the representative use evaluated; see Section 2).

- Soil dissipation studies to provide estimates of DisT50field and DisT90field and/or DegT50field and DegT90field of metabolites KIF-230-M-5 and KIF-230-M-1 under field conditions in at least four different geographical locations were not available (relevant for the representative use evaluated; see Section 4).

- Information to address the compliance of the batches used in the ecotoxicology studies with the technical specification (relevant for the representative use evaluated; see Section 5). 
- Information to address the risk to honeybees from sublethal effects (e.g. effects on hypopharyngeal glands), the risk via guttation and the risk from exposure to contaminated puddle water were not available (relevant for the representative use evaluated; see Section 5).

\section{References}

ECHA and EFSA (European Chemicals Agency and European Food Safety Authority) with the technical support of the Joint Research Centre (JRC), Andersson N, Arena M, Auteri D, Barmaz S, Grignard E, Kienzler A, Lepper P, Lostia AM, Munn S, Parra Morte JM, Pellizzato F, Tarazona J, Terron A and Van der Linden S, 2018. Guidance for the identification of endocrine disruptors in the context of Regulations (EU) No 528/2012 and (EC) No 1107/2009. EFSA Journal 2018;16(6):5311,135 pp. https://doi.org/10.2903/j.efsa.2018.5311. ECHA-18-G-01-EN

EFSA (European Food Safety Authority), 2007. Conclusion regarding the peer review of the pesticide risk assessment of the active substance benthiavalicarb. EFSA Scientific Report 2007;5(8):107r, 81 pp. https://doi. org/10.2903/j.efsa.2007.107r

EFSA (European Food Safety Authority), 2008. Opinion on a request from EFSA related to the default Q10 value used to describe the temperature effect on transformation rates of pesticides in soil. EFSA Journal 2008;6 (1):622, 32 pp. https://doi.org/10.2903/j.efsa.2008.622

EFSA (European Food Safety Authority), 2009. Guidance on Risk Assessment for Birds and Mammals on request from EFSA. EFSA Journal 2009;7(12):1438, 358 pp. https://doi.org/10.2903/j.efsa.2009.1438

EFSA (European Food Safety Authority), 2013. EFSA Guidance Document on the risk assessment of plant protection products on bees (Apis mellifera, Bombus spp. and solitary bees). EFSA Journal 2013;11(7):3295, 268 pp. https://doi.org/10.2903/j.efsa.2013.3295

EFSA (European Food Safety Authority), 2014. Guidance on the assessment of exposure of operators, workers, residents and bystanders in risk assessment for plant protection products. EFSA Journal 2014;12(10):3874, 55 pp. https://doi.org/10.2903/j.efsa.2014.3874 Available online: www.efsa.europa.eu/efsajournal

EFSA (European Food Safety Authority), 2021. Peer review report to the conclusion regarding the peer review of the pesticide risk assessment of the active substance benthiavalicarb. Available online: www.efsa.europa.eu

EFSA PPR Panel (EFSA Panel on Plant Protection Products and their Residues), 2012. Guidance on dermal absorption. EFSA Journal 2012;10(4):2665, 30 pp. https://doi.org/10.2903/j.efsa.2012.2665

EFSA PPR Panel (EFSA Panel on Plant Protection Products and their Residues), 2013. Guidance on tiered risk assessment for plant protection products for aquatic organisms in edge-of-field surface waters. EFSA Journal 2013;11(7):3290, 186 pp. https://doi.org/10.2903/j.efsa.2013.3290

EFSA Scientific Committee, 2012. Scientific Opinion on risk assessment terminology. EFSA Journal 2012;10 (5):2664, 43 pp. https://doi.org/10.2903/j.efsa.2012.2664

European Commission, 2000a. Residues: guidance for generating and reporting methods of analysis in support of pre-registration data requirements for Annex II (Part A, Section 4) and Annex III (Part A, Section 5) of Directive 91/414. SANCO/3029/99-rev. 4, 11 July 2000.

European Commission, 2000b. Technical material and preparations: guidance for generating and reporting methods of analysis in support of pre- and post-registration data requirements for Annex II (Part A, Section 4) and Annex III (Part A, Section 5) of Directive 91/414. SANCO/3030/99-rev. 4, 11 July 2000.

European Commission, 2002a. Guidance Document on Terrestrial Ecotoxicology Under Council Directive 91/414/EEC. SANCO/10329/2002-rev. 2 final, 17 October 2002.

European Commission, 2002b. Guidance Document on Aquatic Ecotoxicology Under Council Directive 91/414/EEC. SANCO/3268/2001-rev. 4 final, 17 October 2002.

European Commission, 2003. Guidance Document on Assessment of the Relevance of Metabolites in Groundwater of Substances Regulated under Council Directive 91/414/EEC. SANCO/221/2000-rev. 10 final, 25 February 2003.

European Commission, 2008. Review report for the active substance benthiavalicarb finalised in the Standing Committee on the Food Chain and Animal Health at its meeting on 22 January 2008 in view of the inclusion of benthiavalicarb in Annex I of Directive 91/414/EEC. SANCO/3917/07 - final, 22 January 2008.

European Commission, 2010. Guidance Document on residue analytical methods. SANCO/825/00-rev. 8.1, 16 November 2010.

European Commission, 2011. Guidelines on comparability, extrapolation, group tolerances and data requirements for setting MRLs. SANCO 7525/VI/95-rev. 9. March 2011. pp. 1-46.

European Commission, 2012. Guidance document on the assessment of the equivalence of technical materials of substances regulated under Regulation (EC) No 1107/2009. SANCO/10597/2003-rev. 10.1, 13 July 2012.

European Commission, 2014a. Assessing potential for movement of active substances and their metabolites to ground water in the EU. Report of the FOCUS Workgroup. EC Document Reference SANCO/13144/2010-v. 3, 613 pp., as outlined in Generic guidance for tier 1 FOCUS groundwater assessment, v. 2.2, May 2014.

European Commission, 2014b. Guidance document on the renewal of approval of active substances to be assessed in compliance with Regulation (EU) No 844/2012. SANCO/2012/11251-rev. 4, 12 December 2014. 
European Commission, 2015. Technical guidance on the interpretation of points 3.6.3. to 3.6.5, and 3.8.2 of Annex II to Regulation (EC) No 1107/2009, in particular regarding the assessment of negligible exposure to an active substance in a plant protection product under realistic conditions of use. SANCO-2014-12096, May 2015.

European Commission, 2021. Guidance document on pesticide analytical methods for risk assessment and postapproval control and monitoring purposes. SANTE/2020/12830-rev. 1, 24 February 2021.

FAO/WHO (Food and Agriculture Organization of the United Nations/World Health Organization), 2009. Risk Characterization of Microbiological Hazards in Food: Guidelines. Microbiological Risk Assessment Series No. 17. Rome. 116 pp.

FOCUS (Forum for the Co-ordination of Pesticide Fate Models and their Use), 2001. FOCUS surface water scenarios in the EU evaluation process under 91/414/EEC. Report of the FOCUS Working Group on Surface Water Scenarios. EC Document Reference SANCO/4802/2001-rev. 2, 245 pp., as updated by Generic guidance for FOCUS surface water scenarios, v. 1.4, May 2015.

FOCUS (Forum for the Co-ordination of Pesticide Fate Models and their Use), 2006. Guidance document on estimating persistence and degradation kinetics from environmental fate studies on pesticides in EU Registration Report of the FOCUS Work Group on Degradation Kinetics. EC Document Reference SANCO/ 10058/2005-v. 2.0, 434 pp., as updated by the Generic guidance for Estimating Persistence and Degradation Kinetics from Environmental Fate Studies on Pesticides in EU Registration, v. 1.1, December 2014.

FOCUS (Forum for the Co-ordination of Pesticide Fate Models and their Use), 2007. Landscape and mitigation factors in aquatic risk assessment. Volume 1. Extended summary and recommendations. Report of the FOCUS Working Group on Landscape and Mitigation Factors in Ecological Risk Assessment. EC Document Reference SANCO/10422/2005 v. 2.0, 169 pp.

JMPR (Joint Meeting on Pesticide Residues), 2004. Report of the Joint Meeting of the FAO Panel of Experts on Pesticide Residues in Food and the Environment and the WHO Core Assessment Group on Pesticide Residues, Rome, Italy, 20-29 September 2004, 383 pp.

JMPR (Joint Meeting on Pesticide Residues), 2007. Report of the Joint Meeting of the FAO Panel of Experts on Pesticide Residues in Food and the Environment and the WHO Core Assessment Group on Pesticide Residues, Geneva, Switzerland, 18-27 September 2007, 164 pp.

McCall PJ, Laskowski DA, Swann RL and Dishburger HJ, 1980. Measurements of sorption coefficients of organic chemicals and their use in environmental fate analysis. In: Test Protocols for Environmental Fate and Movement of Toxicants. In: Proceedings of the 94th Annual Meeting of the American Association of Official Analytical Chemists (AOAC). Oct 21-22, Washington, D.C. pp. 89-109.

OECD (Organisation for Economic Co-operation and Development), 2009. Guidance document on overview of residue chemistry studies. ENV/JM/MONO(2009)31, 28 July 2009.

OECD (Organisation for Economic Co-operation and Development), 2011. OECD MRL calculator: spreadsheet for single data set and spreadsheet for multiple data set, 2 March 2011. In: Pesticide Publications/Publications on Pesticide Residues. Available online: www.oecd.org

Poland, 2017. Renewal Assessment Report (RAR) on the active substance benthiavalicarb-isopropyl prepared by the rapporteur Member State Poland, in the framework of Commission Implementing Regulation (EU) No 844/ 2012, October 2017. Available online: www.efsa.europa.eu

Poland, 2021. Revised Renewal Assessment Report (RAR) on benthiavalicarb-isopropyl prepared by the rapporteur Member State Poland in the framework of Commission Implementing Regulation (EU) No 844/2012, June 2021. Available online: www.efsa.europa.eu

SETAC (Society of Environmental Toxicology and Chemistry), Candolfi MP, Barrett KL, Campbell PJ, Forster R, Grandy N, Huet MC, Lewis G, Oomen PA, Schmuck R and Vogt H, eds, 2001. Guidance document on regulatory testing and risk assessment procedures for plant protection products with non-target arthropods. ESCORT 2 workshop.

\section{Abbreviations}

$\begin{array}{ll}1 / n & \text { slope of Freundlich isotherm } \\ \lambda & \text { wavelength } \\ \varepsilon & \text { decadic molar extinction coefficient } \\ \text { ADE } & \text { actual dermal exposure } \\ \text { ADI } & \text { acceptable daily intake } \\ \text { AF } & \text { assessment factor } \\ \text { AAOEL } & \text { acute acceptable operator exposure level } \\ \text { AOEL } & \text { acceptable operator exposure level } \\ \text { AR } & \text { applied radioactivity } \\ \text { AR } & \text { androgen receptor } \\ \text { ARfD } & \text { acute reference dose } \\ \text { AV } & \text { avoidance factor } \\ \text { BUN } & \text { blood urea nitrogen }\end{array}$




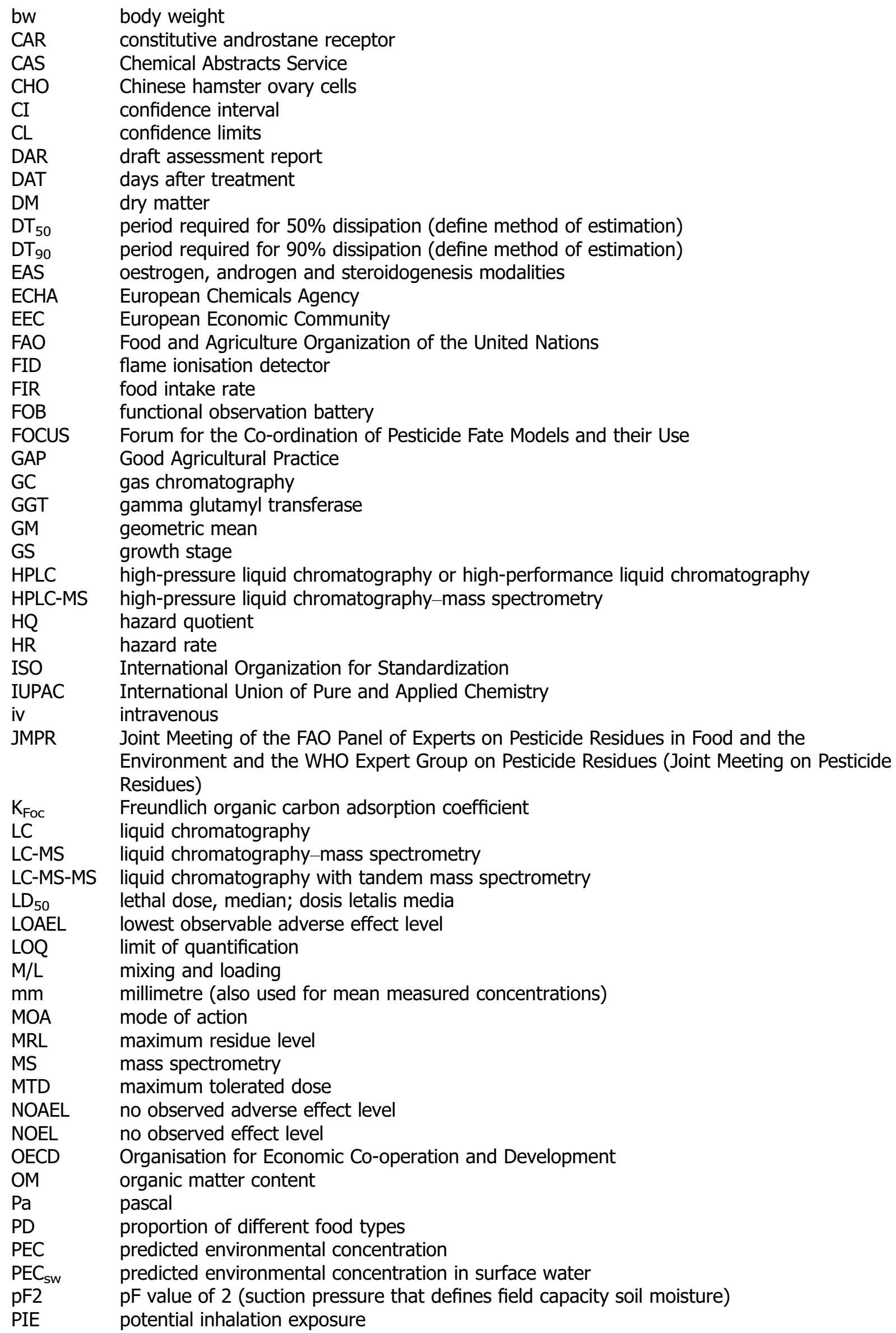


RAC regulatory acceptable concentration

RAR Renewal Assessment Report

RBC red blood cells

REACH Registration, Evaluation, Authorisation of Chemicals Regulation

SC suspension concentrate

SFO single first-order

SMILES simplified molecular-input line-entry system

TK technical concentrate

TRR total radioactive residue

TSH thyroid-stimulating hormone (thyrotropin)

TWA time-weighted average

UF uncertainty factor

UV ultraviolet

W/S water/sediment

$w / v \quad$ weight per unit volume

w/w weight per unit weight

WBC white blood cell

WG water-dispersible granule

WHO World Health Organization 


\section{Appendix A - Consideration of cut-off criteria for benthiavalicarb according to Annex II of Regulation (EC) No 1107/2009 of the European Parliament and of the Council}

\begin{tabular}{|c|c|c|}
\hline \multicolumn{2}{|c|}{ Properties } & \multirow{2}{*}{$\begin{array}{l}\text { Conclusion }{ }^{(a)} \\
\text { Benthiavalicarb-isopropyl may be considered to meet the criteria for } \\
\text { Carcinogenic Cat } 1 \text { B according to Reg. 1272/2008. This is based on peer } \\
\text { review experts' outcome; however, classification to be confirmed by ECHA } \\
\text { (Cat. } 2 \text { proposed to ECHA). See Section } 2 \text {. }\end{array}$} \\
\hline CMR & Carcinogenicity (C) & \\
\hline & Mutagenicity (M) & $\begin{array}{l}\text { Benthiavalicarb-isopropyl is not considered to be mutagenic according to } \\
\text { point 3.6.2 of Annex II of Regulation (EC) } 1107 / 2009 \text {. }\end{array}$ \\
\hline & $\begin{array}{l}\text { Toxic for } \\
\text { Reproduction (R) }\end{array}$ & $\begin{array}{l}\text { Benthiavalicarb-isopropyl is not considered to be toxic for reproduction } \\
\text { according to point 3.6.4 of Annex II of Regulation (EC) } 1107 / 2009 \text {. }\end{array}$ \\
\hline \multicolumn{2}{|c|}{$\begin{array}{l}\text { Endocrine-disrupting } \\
\text { properties }\end{array}$} & $\begin{array}{l}\text { Benthiavalicarb-isopropyl is considered to meet the criteria for endocrine } \\
\text { disruption for humans for the T and EAS modalities according to point } 3.6 .5 \\
\text { of Annex II of Regulation No } 1107 / 2009 \text {, as amended by Commission } \\
\text { Regulation (EU) } 2018 / 605 \text {. } \\
\text { The endocrine-disrupting properties of benthiavalicarb-isopropyl for non- } \\
\text { target organisms according to point } 3.8 .2 \text { of Annex II to Regulation (EC) } \\
\text { No } 1107 / 2009 \text {, as amended by Commission Regulation (EU) } 2018 / 605 \\
\text { could not be concluded. }\end{array}$ \\
\hline \multirow[t]{2}{*}{ POP } & Persistence & \multirow{2}{*}{$\begin{array}{l}\text { Benthiavalicarb-isopropyl is not considered to be a persistent organic } \\
\text { pollutant (POP) according to point 3.7.1 of Annex II of Regulation (EC) } \\
1107 / 2009 .\end{array}$} \\
\hline & $\begin{array}{l}\text { Bioaccumulation } \\
\text { Long-range transport }\end{array}$ & \\
\hline \multirow[t]{3}{*}{ PBT } & Persistence & \multirow{3}{*}{$\begin{array}{l}\text { Benthiavalicarb-isopropyl is not considered to be a persistent, } \\
\text { bioaccumulative and toxic (PBT) substance according to point } 3.7 .2 \text { of } \\
\text { Annex II of Regulation (EC) 1107/2009. }\end{array}$} \\
\hline & Bioaccumulation & \\
\hline & Toxicity & \\
\hline \multirow[t]{2}{*}{ vPvB } & Persistence & \multirow{2}{*}{$\begin{array}{l}\text { Benthiavalicarb-isopropyl is not considered to be a very persistent, very } \\
\text { bioaccumulative substance according to point } 3.7 .3 \text { of Annex II of } \\
\text { Regulation (EC) } 1107 / 2009 \text {. }\end{array}$} \\
\hline & Bioaccumulation & \\
\hline
\end{tabular}

(a): Origin of data to be included where applicable (e.g. EFSA, ECHA RAC, Regulation). 


\section{Appendix B - List of end points for the active substance and the} representative formulation

Appendix B can be found in the online version of this output ('Supporting information' section): https://doi.org/10.2903/j.efsa.2021.6833 
Appendix C - Evaluation of data concerning the necessity of benthiavalicarb as a fungicide to control a serious danger to plant health which cannot be contained by other available means, including nonchemical methods

Appendix $C$ can be found in the online version of this output ('Supporting information' section): https://doi.org/10.2903/j.efsa.2021.6833 


\section{Appendix D - Data collection set}

Validated Excel files submitted by MS (Austria, 2020; Belgium, 2020; Denmark, 2020; Germany, 2020; Italy, 2020; the Netherlands, 2020; Poland, 2020) and evaluated by EFSA.

Appendix D can be found in the online version of this output ('Supporting information' section): https://doi.org/10.2903/j.efsa.2021.6833 


\section{Appendix E - Wording EFSA used in section 4 of this conclusion, in relation to DT and Koc 'classes' exhibited by each compound assessed}

\begin{tabular}{l|l}
\hline Wording & $\begin{array}{l}\text { DT }_{\mathbf{5 0}} \text { normalised to } \mathbf{2 0}^{\circ} \mathbf{C} \text { for laboratory incubations } \\
\text { field studies (SFO equivalent, when biphasic, the } \mathbf{D T}_{\mathbf{9 0}} \text { was divided by } \mathbf{3 . 3 2} \text { to } \\
\text { estimate the DT50 when deciding on the wording to use) }\end{array}$ \\
\hline $\begin{array}{l}\text { Very low } \\
\text { persistence }\end{array}$ & $<1$ day \\
\hline $\begin{array}{l}\text { Low persistence } \\
\text { Moderate } \\
\text { persistence }\end{array}$ & $1-<10$ days \\
\hline $\begin{array}{l}\text { Medium persistence } \\
\text { High persistence }\end{array}$ & $10-<60$ days \\
\hline $\begin{array}{l}\text { Very high } \\
\text { persistence }\end{array}$ & A year or more \\
\hline
\end{tabular}

Note these classes and descriptions are unrelated to any persistence class associated with the active substance cut-off criteria in Annex II of Regulation (EC) No 1107/2009. For consideration made in relation to Annex II, see Appendix A.

(a): For laboratory soil incubations, normalisation was also to field capacity soil moisture ( $\mathrm{pF} 2 / 10 \mathrm{kPa})$. For laboratory sediment water system incubations, the whole system DT values were used.

\begin{tabular}{l|c}
\hline Wording & $\mathbf{K}_{\mathbf{o c}}\left(\mathbf{e i t h e r} \mathbf{K}_{\mathbf{F o c}} \mathbf{\text { or }} \mathbf{K}_{\mathbf{d o c}}\right) \mathbf{~} \mathbf{~ L /} \mathbf{g}$ \\
\hline Very high mobility & $0-50$ \\
\hline High mobility & $51-150$ \\
\hline Medium mobility & $151-500$ \\
\hline Low mobility & $501-2,000$ \\
\hline Slight mobility & $2,001-5,000$ \\
\hline Immobile & $>5,000$ \\
\hline
\end{tabular}

Based on McCall et al. (1980). 


\section{Appendix F - Used compound codes}

\begin{tabular}{|c|c|c|}
\hline $\begin{array}{l}\text { Code/trivial } \\
\text { name }^{(a)}\end{array}$ & IUPAC name/SMILES notation/InChiKey ${ }^{(\mathbf{b})}$ & Structural formula(c) \\
\hline benthiavalicarb & $\begin{array}{l}{[(1 S)-1-\{[(1 R)-1-(6-\text { fluoro-1,3-benzothiazol-2-yl) }} \\
\text { ethyl]carbamoyl }\}-2-\text {-methylpropyl]carbamic acid } \\
\mathrm{CC}(\mathrm{C})[\mathrm{C} @ \mathrm{H}](\mathrm{NC}(=\mathrm{O}) \mathrm{O}) \mathrm{C}(=\mathrm{O}) \mathrm{N}[\mathrm{C} @ \mathrm{H}](\mathrm{C}) \mathrm{c} 1 \mathrm{nc} 2 \mathrm{ccc} \\
\text { (F)cc2s1 } \\
\text { VVSLYIKSEBPRSN-PELKAZGASA-N }\end{array}$ & $\overline{\mathrm{C}} \mathrm{H}_{3}$ \\
\hline $\begin{array}{l}\text { benthiavalicarb- } \\
\text { isopropyl } \\
(\text { KIF-230R-L) }\end{array}$ & $\begin{array}{l}\text { isopropyl }[(S)-1-\{[(1 R)-1-(6 \text {-fluoro-1,3- } \\
\text { benzothiazol-2-yl)ethyl]carbamoyl }\}-2-\text {-methylpropyl }] \\
\text { carbamate } \\
\mathrm{CC}(\mathrm{C})[\mathrm{C@H}](\mathrm{NC}(=\mathrm{O}) \mathrm{OC}(\mathrm{C}) \mathrm{C}) \mathrm{C}(=\mathrm{O}) \mathrm{N}[\mathrm{C} @ \mathrm{H}](\mathrm{C}) \\
\mathrm{c} 1 \mathrm{nc} 2 \mathrm{ccc}(\mathrm{F}) \mathrm{cc} 2 \mathrm{~s} 1 \\
\text { USRKFGIXLGKMKU-ABAIWWIYSA-N }\end{array}$ & \\
\hline KIF-230S-L & $\begin{array}{l}\text { isopropyl }[(S)-1-\{[(1 S)-1-(6 \text {-fluoro-1,3- } \\
\text { benzothiazol-2-yl)ethyl]carbamoyl }\}-2-\text {-methylpropyl }] \\
\text { carbamate } \\
\mathrm{CC}(\mathrm{C})[\mathrm{C} @ \mathrm{H}](\mathrm{NC}(=\mathrm{O}) \mathrm{OC}(\mathrm{C}) \mathrm{C}) \mathrm{C}(=\mathrm{O}) \mathrm{N}[\mathrm{C} @ @ \mathrm{H}](\mathrm{C}) \\
\text { c1nc2ccc(F)cc2s1 } \\
\text { USRKFGIXLGKMKU-NHYWBVRUSA-N }\end{array}$ & \\
\hline KIF-230S-D & $\begin{array}{l}\text { isopropyl }[(S)-1-\{[(1 R)-1-(6 \text {-fluoro-1,3- } \\
\text { benzothiazol-2-yl)ethyl]carbamoyl }\}-2-\text {-methylpropyl }] \\
\text { carbamate } \\
\mathrm{CC}(\mathrm{C})[\mathrm{C} @ @ \mathrm{H}](\mathrm{NC}(=\mathrm{O}) \mathrm{OC}(\mathrm{C}) \mathrm{C}) \mathrm{C}(=\mathrm{O}) \mathrm{N}[\mathrm{C} @ @ \mathrm{H}](\mathrm{C}) \\
\text { c1nc2ccc(F)cc2s1 } \\
\text { USRKFGIXLGKMKU-XHDPSFHLSA-N }\end{array}$ & \\
\hline KIF-230R-D & $\begin{array}{l}\text { isopropyl }[(R)-1-\{[(1 R)-1-(6 \text {-fluoro-1,3- } \\
\text { benzothiazol-2-yl)ethyl]carbamoyl }\}-2-\text {-methylpropyl }] \\
\text { carbamate } \\
\mathrm{CC}(\mathrm{C})[\mathrm{C} @ @ \mathrm{H}](\mathrm{NC}(=\mathrm{O}) \mathrm{OC}(\mathrm{C}) \mathrm{C}) \mathrm{C}(=\mathrm{O}) \mathrm{N}[\mathrm{C} @ \mathrm{H}](\mathrm{C}) \\
\mathrm{c} 1 \mathrm{nc} 2 \mathrm{ccc}(\mathrm{F}) \mathrm{cc} 2 \mathrm{~s} 1 \\
\text { USRKFGIXLGKMKU-IAQYHMDHSA-N }\end{array}$ & \\
\hline KIF-230-M-1 & $\begin{array}{l}\text { 6-fluoro-1,3-benzothiazol-2-ol } \\
\text { Fc1ccc2nc(O)sc2c1 } \\
\text { HCFZOCSVSDAYQF-UHFFFAOYSA-N }\end{array}$ & \\
\hline KIF-230-M-3 & $\begin{array}{l}\text { 1-(6-fluoro-1,3-benzothiazol-2-yl)ethan-1-ol } \\
\mathrm{CC}(0) \text { c1nc2ccc(F)cc2s1 } \\
\text { KMABBBXOJRAOKB-UHFFFAOYSA-N }\end{array}$ & \\
\hline KIF-230-M-4 & $\begin{array}{l}\text { 1-(6-fluoro-1,3-benzothiazol-2-yl)ethan-1-one } \\
\mathrm{CC}(=0) \mathrm{c} 1 \mathrm{nc} 2 \mathrm{ccc}(\mathrm{F}) \mathrm{cc} 2 \mathrm{~s} 1 \\
\text { GUNCTJJQHILPGA-UHFFFAOYSA-N }\end{array}$ & \\
\hline
\end{tabular}




\begin{tabular}{|c|c|c|}
\hline $\begin{array}{l}\text { Code/trivial } \\
\text { name }^{(a)}\end{array}$ & IUPAC name/SMILES notation/InChiKey ${ }^{(\mathbf{b})}$ & Structural formula(c) \\
\hline KIF-230-M-5 & $\begin{array}{l}\text { 1-(6-fluoro-1,3-benzothiazol-2-yl)ethan-1-amine } \\
\text { CC(N)c1nc2ccc(F)cc2s1 } \\
\text { LMYJCUHGXCJZJF-UHFFFAOYSA-N }\end{array}$ & \\
\hline KIF-230-M-8 & $\begin{array}{l}\mathrm{N} \text {-[1-(6-fluoro-1,3-benzothiazol-2-yl)ethyl] } \\
\text { acetamide } \\
\mathrm{CC}(=\mathrm{O}) \mathrm{NC}(\mathrm{C}) \mathrm{c} 1 \mathrm{nc} 2 \mathrm{ccc}(\mathrm{F}) \mathrm{cc} 2 \mathrm{~s} 1 \\
\text { CLBBOKYRCBGANT-UHFFFAOYSA-N }\end{array}$ & \\
\hline
\end{tabular}

(a): The metabolite name in bold is the name used in the conclusion.

(b): ACD/Name 2019.1.1 ACD/Labs 2019 Release (File version N05E41, Build 110555, 18 July 2019).

(c): ACD/ChemSketch 2019.1.1 ACD/Labs 2019 Release (File version C05H41, Build 110712, 24 July 2019). 